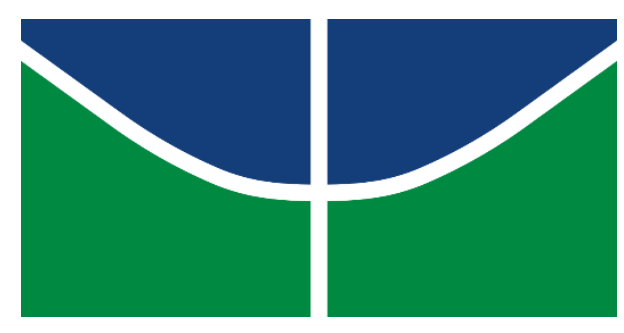

\author{
UNIVERSIDADE DE BRASÍLIA \\ FACULDADE DE EDUCAÇÃO - FE \\ CURSO DE PEDAGOGIA
}

OS PROCESSOS DE ALIMENTAÇÃO NA EDUCAÇÃO INFANTIL: ESTUDO DE CASO SOBRE A PRÁTICA NO AMBIENTE ESCOLAR COM CRIANÇAS DE TRÊS ANOS

GISELE KAROLINA NASCIMENTO DE FREITAS

Brasília - DF

2019 


\title{
OS PROCESSOS DE ALIMENTAÇÃO NA EDUCAÇÃO INFANTIL: ESTUDO DE CASO SOBRE A PRÁTICA NO AMBIENTE ESCOLAR COM CRIANÇAS DE TRÊS ANOS
}

\begin{abstract}
Monografia apresentada à Comissão Examinadora da Faculdade de Educação da Universidade de Brasília - UnB, como requisito parcial para obtenção do título em Pedagogia - licenciatura plena, sob a orientação do Professor Dr. Francisco José Rengifo-Herrera.
\end{abstract}

Brasília - DF 
FOLHA DE APROVAÇÃO

GISELE KAROLINA NASCIMENTO DE FREITAS

\title{
OS PROCESSOS DE ALIMENTAÇÃO NA EDUCAÇÃO INFANTIL: ESTUDO DE CASO SOBRE A PRÁTICA NO AMBIENTE ESCOLAR COM CRIANÇAS DE 3 ANOS.
}

\author{
Aprovado em \\ Comissão Examinadora
}

Prof. Dr. Francisco José Rengifo-Herrera (Orientador)

Faculdade de Educação/Universidade de Brasília

Prof.Dra. Monique Voltarelli (Examinadora)

Faculdade de Educação/Universidade de Brasília

Prof. Dra. Sandra Ferraz (Examinadora)

Faculdade de Educação/Universidade de Brasília

Prof. Dra. Alia Barros (Suplente)

Faculdade de Educação/Universidade de Brasília 
Dedico este trabalho a Deus, minha família e meu namorado por toda força, apoio e incentivo. Gratidão. 


\section{AGRADECIMENTOS}

Agradeço a Deus que em sua infinita bondade, me permitiu chegar até aqui, me proporcionando belas experiências.

Aos meus pais Roseanne e Adelmo, por todo apoio, cuidado, paciência, incentivo, compreensão e amor. Por acreditarem em meu potencial e nunca deixarem eu desistir, sempre me motivando e me fazendo acreditar que os dias ruins passariam.

As minhas irmãs Jessyca e Geovanna, por sempre transformarem meus estresses em boas risadas ou em boas confusões.

Ao meu namorado Gabriel, por estar me acompanhando desde o fim do Ensino Médio, sempre me dando apoio, amor, cuidado e incentivo em cada jornada, obrigada pela paciência e compreensão nesse momento decisivo.

As minhas amigas de faculdade Aline e Amanda, por ouvirem cada lamento, desespero e cansaço, sempre com bom humor, transformando minhas indignações em belos aprendizados.

As minhas amigas do primeiro estágio Ana Alice, Lucimara e Vanúcia por tornarem minhas tardes mais alegres, pelo carinho, e incentivo em prosseguir nessa jornada. Ao meu orientador por todo cuidado, paciência e incentivo.

A todos que cruzaram meu caminho e me fizeram crescer como pessoa e profissional, a minha eterna gratidão. 


\section{RESUMO}

O presente estudo buscou caracterizar a forma como se dá os objetos nos processos de alimentação na Educação Infantil. A observação e análise focaram nas ações e diálogos expressos ao longo de diferentes momentos de observação, em situações de alimentação de duas crianças de 3 anos no contexto escolar. O problema de pesquisa procurou identificar a forma como se desenvolve a relação triádica entre as crianças, o objeto e as educadoras no momento da refeição. $O$ objetivo é analisar as ações e diálogos que surgem durante os momentos de alimentação a respeito do uso convencional dos objetos no contexto educacional. No processo metodológico, foi utilizada a pesquisa derivando uma análise microgenética, com entrevistas semiestruturadas, filmagens, observação e foto, realizadas em uma creche pública de horário integral conveniada ao Governo do Distrito Federal. Com base nas análises, foi notado que apesar dos projetos voltados a alimentação, o momento no refeitório ainda é considerado mais biológico do que pedagógico.

Palavras-chave: Alimentação; Autonomia; Comunicação; Triadicidade. 


\begin{abstract}
The present study sought to characterize the way in which dialogue and the use of objects in the feeding processes are carried out in Early Childhood Education. Observation and analysis focused on the actions and dialogues expressed during different moments of observation, in feeding situations of two 3 year old children in the school context. The research problem looked for identify how the triadic relationship develops between the children, the object and the educators at the time of the meal. The objective is to analyze the actions and dialogues that arise during feeding moments regarding the conventional use of objects in the educational context. In the methodological process, the research was used to derive a microgenetic analysis, with semistructured interviews, filming, observation and photograph, carried out in a public nursery full time agreed to the Government of the Federal District. Based on the analyzes, it was noted that despite the food-related projects, the time in the refectory is still considered more biological than pedagogical.
\end{abstract}

Keywords: Food; Autonomy; Communication; Dialogicity; Triadicidade. 


\section{LISTA DE FIGURAS}

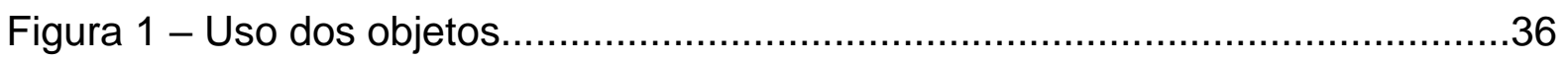

Figura 2 - Comunicação e alimentação........................................................... 44 


\section{SUMÁRIO}

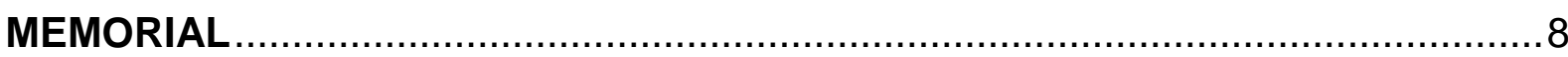

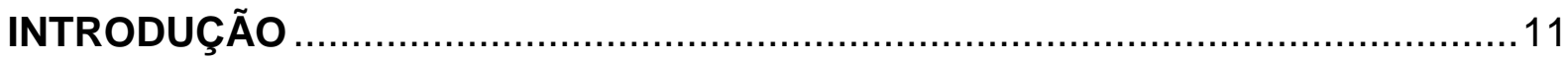

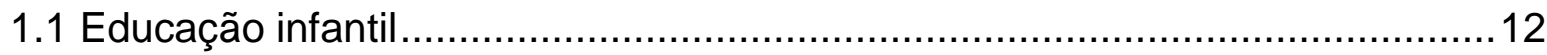

1.2 A criança e os objetos nos processos de alimentação...............................15

1.3 O relacionamento no aspecto semiótico e a triadicidade ..............................17

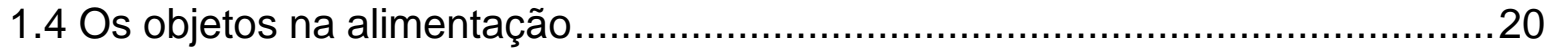

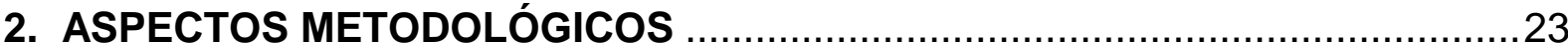

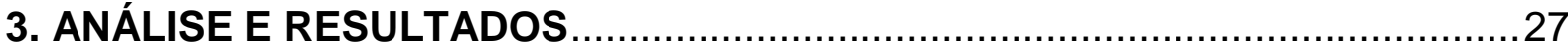

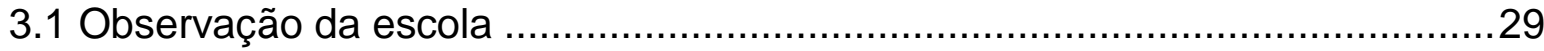

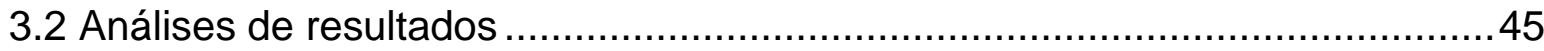

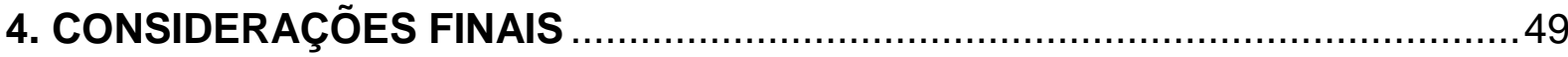

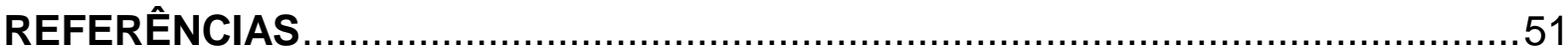

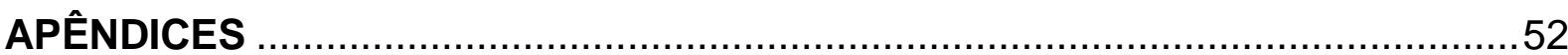

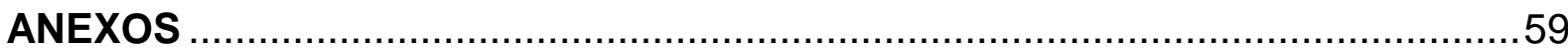




\section{MEMORIAL}

Sou natural de Porto Trombetas - PA, minha mãe se chama Roseanne e meu pai Adelmo, ela é paraense e ele é pernambucano, eu sou a filha do meio, a mais velha se chama Jessyca e a caçula Geovanna. Minha infância se passou em diferentes lugares do Brasil. A fase que marcou minha infância foi quando morei no Rio de Janeiro, em um bairro chamado Guadalupe. Eu tinha cerca de seis anos de idade, em 2002, mas lembro de algumas coisas, justamente por ter sido uma fase na qual eu aproveitei bastante, mesmo com o índice alto de violência no bairro pude brincar e aproveitar com as crianças da vizinhança e da escola, porém na maior parte do tempo dentro da casa de algumas delas.

Minha trajetória escolar começou por volta dos três anos de idade inicialmente na escolinha Walt Disney, em Brasília, de onde tenho minha primeira memória dentro de um ambiente escolar. Lembro-me de estar em uma festinha infantil de algum coleguinha da escola, onde tinha diversos personagens de filmes infantis. Meu ensino fundamental 1 ocorreu inicialmente no Rio de Janeiro onde fiz até a $3^{\circ}$ série, era uma instituição particular chamada Escolas Integradas Fausto Cardoso com um espaço interno bem amplo, 3 andares e uma quadra com arquibancada, tínhamos aula de informática na grade curricular e era ofertado aula de capoeira e de música (flauta), no horário contrário ao da aula. Eu participava apenas das aulas de música (2x por semana), criei um amor muito grande pela flauta a partir dessas aulas. Já aqui em Brasília iniciei a 4ํㅗ série em uma escola pública chamada Classe 05 localizada no Guará I, era a escola ao qual minha irmã já tinha estudado na primeira vez que moramos em Brasília. No Ensino Fundamental II estudei também em uma escola pública chamada CEF 02 (Centro de Ensino Fundamental 02 do Guará), que por sinal era uma escola muito almejada por ser umas das melhores do bairro na época, era ofertado aula de música (com outro nome) na grade curricular, ensaiávamos para tocar na banda, eu em particular toquei trombone e prato. $\mathrm{O}$ ensino médio realizei em duas escolas distintas uma no Guará (2011) e outra no Plano Piloto (2012-2013) ambas públicas, o primeiro ano do ensino médio realizei no Centro de Ensino Médio 02 do Guará muito conhecido como GG, onde um dos maiores eventos da escola era o interclasse, eram duas semanas com diversas atividades diferentes e competições, no qual a escola era dividida em várias equipes 
mistas (turmas e anos diferentes) e a vencedora ganharia um dia em um hotel fazenda no entorno de Brasília, em 2011 minha equipe venceu. Por motivos de saúde da minha mãe, nos mudamos para a Asa Sul no ano de 2012, no qual iniciei o segundo ano do ensino médio no colégio CEMSL (Centro de Ensino Médio Setor Leste), foi um período difícil, pois me distanciei dos amigos que fiz no Guará e tive que me readaptar ao novo lugar de moradia e a nova escola. No ano de 2013 iniciei e concluí o Ensino médio no CEMSL, a escola possuía diversos projetos, dentre os quais tinha a Feira Gastronômica, Semana de Arte e Cultura, Feira de Ciências e o Projeto Re(vi)vendo Éxodos, o que me trouxe uma bagagem cultural e social bem grande.

Todas essas mudanças se deram em decorrência da profissão do meu pai, ele é militar. Então, por conta do trabalho dele tivemos que nos mudar diversas vezes, mas pudemos conhecer outros lugares, o que foi muito bom, pois tivemos a chance de conhecer pessoas novas e lugares diferentes, mas também foi ruim por termos de deixá-las. Depois de concluir o Ensino Médio aos dezessete anos, esperei seis meses até conseguir, finalmente passar no vestibular da UnB - Universidade de Brasília. A princípio tentei o Vestibular e o PAS para Serviço Social, mas felizmente não consegui passar, então por certa influência da minha mãe e por sempre querer trabalhar diretamente com crianças prestei o vestibular para pedagogia e consegui ingressar no curso da Faculdade de Educação em agosto de 2014. Foi uma grande alegria e vitória para mim e todos da minha família. Meus pais ficaram felizes e exultantes, afinal, eu era a segunda filha a ingressar em uma Universidade pública considerada de excelência. Quando cheguei ao terceiro semestre tive a oportunidade de estagiar em uma escola particular na W3 Norte, como auxiliar de sala, trabalhei com três turmas de idades diferentes ( 3,4 e 5 anos), durante esse período tive ótimas experiências e aprendi muito com cada professora com quem fiquei, além de colocarem prática algumas teorias e ideias que obtive das aulas na faculdade, fiquei nesse estágio até 07/2017 (6º semestre).Ainda no mês de Julho/2017 ingressei em outra escola particular, localizada no Lago Sul, lá trabalhei com crianças de 1 anos e 7 meses há 2 anos, foi uma experiência gratificante, mas muito cansativa, pois todo o cuidado pessoal, higiene e alimentação era feito por mim e mais duas auxiliares.

No final de 2017, meu pai aposentou da Marinha e tivemos que nos mudar de RA novamente, então compramos um apartamento na Samambaia onde moro 
atualmente. Foi um período muito estressante, pois além de estar tendo aulas na faculdade, eu estava trabalhando muito longe de casa, o percurso era cansativo e o trabalho na escola era árduo. Foi então que surgiu a oportunidade de trabalhar perto da minha residência, seria duas horas a menos de estágio se comparado a escola do Lago Sul. Fiz os processos seletivos e passei para trabalhar com crianças de 5 anos tendo o início desse estágio em Fevereiro/2018. Decidi que até que as aulas na UnB não começassem eu ficaria nos dois estágios, trabalhando então o dia todo, até que encerrei meu contrato em Março/2018 no Lago Sul e fiquei apenas na escola de Samambaia.

Por escolha minha, tive que conciliar estudos e estágio o que dificultou um pouco na escolha do horário das aulas, por conta disso não consegui cursar todas as disciplinas que desejava por conta das ofertas limitadas, muito menos dos projetos de extensão que a faculdade tinha a oferecer. Tive dificuldades com alguns professores por eles não entenderem essa rotina cansativa de estudar de manhã, estagiar a tarde e voltar pra UnB a noite, mas acredito que essas situações foram para mostrar que sou capaz de conseguir o que tanto desejo, basta ter perseverança e força de vontade, apesar disso me sinto realizada quanto à minha formação acadêmica obtida na Universidade de Brasília, em especial na Faculdade de Educação. O curso de Pedagogia tem em sua composição cinco Projetos curriculares, estes têm como objetivo envolver o aluno dentro da vivência prática e reflexiva das atividades de ensino pesquisa e extensão. Infelizmente cada projeto fiz com um professor diferente, pois mesmo com muita insistência a maioria dos docentes só aceitavam alunos que estavam realizando PIBIC com eles nos semestres anteriores. Felizmente no segundo semestre de 2018, encontrei o professor Francisco Herrera, que me propôs abordar o tema da alimentação no ambiente escolar. Chegando então ao tema final "Os processos de alimentação na Educação Infantil: Estudo de caso sobre a prática no ambiente escolar com crianças de três anos". O tema se fez muito pertinente para mim, visto que durante os anos de estágio nas escolas pude observar o quanto a alimentação é tratada apenas como uma necessidade biológica, deixando de lado as práticas pedagógicas que envolvem

0 processo de aprendizagem. 


\section{INTRODUÇÃO}

Este trabalho visa analisar as ações e diálogos expressos ao longo de diferentes momentos de observação, em situações de alimentação de duas crianças de três anos no contexto escolar. O uso dos objetos está associado com aspectos que envolvem 0 incentivo a envolvê-los nas ações cotidianas em diversos momentos, bem como os processos de engajamento cultural que essa aprendizagem das maneiras de serem utilizados envolve durante diversos momentos de alimentação de crianças na idade entre dois e três anos. Reconhecendo a alimentação como uma atividade que vai além de uma experiência pedagógica, é de suma importância considerar que envolve aspectos sobre identidade, construção dialógica da relação com o outro e com o mundo. A alimentação envolve aspectos relacionados com a vida e desenvolvimento das crianças, melhorando sua autonomia, incrementando o paladar, refletindo sobre diferentes aspectos que envolvem afetividade, identidade e práticas cotidianas a respeito das características e posicionamentos que sua cultura tem construído sobre o mundo. Igualmente, ampliando suas experiências sensoriais e cognitivas sobre o mundo que o rodeia. O objetivo geral pretende analisar os diálogos e as ações expressas em contextos presentes nos usos dos objetos em situações alimentares na escola, desde uma perspectiva triádica.

Dentro destas perspectivas, usaremos autores que abordam o assunto de forma crítica, demonstrando a real importância do adulto neste processo. O respaldo teórico foi fundamentado em: Rodríguez e Moro (2002), Rodríguez (2009), Español (2004) e (2005), Rappaport (1981), SEDF (2013), LDB (1996) e PDE (2015). No primeiro capítulo apresentaremos: A Educação Infantil,

No embasamento teórico apresentaremos primeiro a triadicidade e desenvolvimento: um olhar contemporâneo aos processos educacionais, em segundo, a criança e os objetos nos processos de alimentação, e em terceiro, o relacionamento no aspecto semiótico. No capítulo dois e três, trataremos dos aspectos metodológicos com a contextualização da creche observada, a descrição das situações selecionadas como momentos chave para esse estudo, a análise das cenas observadas e as respostas das entrevistas feitas com as monitoras e 
nutricionista. Por fim, no capítulo quatro será realizada a integração da escola na análise dos dados, seguida da consideração, apêndice e anexos.

\subsection{Educação infantil}

A educação infantil surge a partir da Constituição Federal de 1988, antes da lei o atendimento a criança tinha um caráter assistencialista/compensatório, que acompanhando a crescente urbanização, tinha como um dos intuitos o de auxiliar/liberar as mulheres que trabalhavam fora de casa.

[...] eram as creches que surgiam, com caráter assistencialista, visando afastar as crianças pobres do trabalho servil que o sistema capitalista em expansão Ihes impunha, além de servirem como guardiãs de crianças órfãs e filhas de 37 trabalhadores. Nesse sentido, a pré-escola tinha como função precípua a guarda de crianças (KRAMER, 2009, p. 23)

Desde a Constituição Federal de 1988 a educação em espaços coletivos é uma questão de direitos das crianças e, a partir da Lei № 9394/96 (LDB), a Educação Infantil é considerada a primeira etapa da educação básica. Sendo assim a Educação Infantil, segundo o artigo 29 da LDB, tem como finalidade "o desenvolvimento integral da criança até 05 anos em seus aspectos físico psicológico, intelectual e social, completando a ação da família e comunidade". Atualmente são encontrada diversas leis que visam a proteção integral da criança e a garantia dos seus direitos sociais, resultado das Diretrizes Curriculares Nacionais para Educação Infantil (DCNEI), que na Resolução CNE/CEB no 5/2009/29, em seu Artigo 4 definem a criança como "sujeito histórico e de direitos, que interage, brinca, imagina, fantasia, deseja, aprende, observa, experimenta, narra, questiona e constrói sentidos sobre a natureza e a sociedade, produzindo cultura.

As leis que regem a Educação Infantil no Brasil destacam alguns deveres básicos que devem ser assegurados para o adequado desenvolvimento físico, intelectual, e social da criança. Sendo assim, a LDB destaca em seu texto algumas exigências mínimas obrigatórias que devem ser cumpridas pela família, sociedade e escola. 
pleno desenvolvimento do educando, seu preparo para o exercício da cidadania e sua qualificação para o trabalho.

Dessa forma, no ano de 2003, houve uma alteração na LDBEN 9.394/1996,

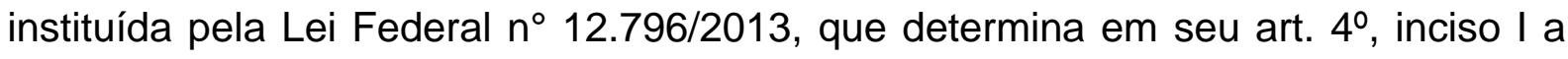
"educação básica obrigatória e gratuita dos 4 (quatro) aos 17 (dezessete) anos de idade", além da gratuidade para crianças até 5 (cinco) anos de idade.

Para garantir que sejam cumpridas todas as exigências para o bem-estar da criança, a União incumbiu-se de elaborar um Plano Nacional de Educação junto ao Distrito Federal, Municípios e Estados visando atender as necessidades regionais, além de coletar, analisar e disseminar informações sobre a educação. Dessa forma, fica sob a responsabilidade do educador a elaboração da proposta pedagógica, a aprendizagem das crianças e $o$ incentivo a atividades que promovam a participação da família e comunidade na escola.

Diante da exigência da União, foi elaborado o Plano Distrital de Educação (Lei no 5.499, de 14/7/2015) com vigência até 2024. O Governo do Distrito Federal no Anexo I estabelece algumas metas e estratégias a serem cumpridas nesse tempo, dentre as quais está:

1.14 - Orientar às instituições educacionais que atendem crianças de 0 a 5 anos que agreguem ou ampliem, em suas práticas pedagógicas cotidianas, ações que visem ao enfrentamento da violência, a inclusão e o respeito, a promoção da saúde e dos cuidados, a convivência escolar saudável e o estreitamento da relação família-criança-instituição.

1.15 - Garantir a alimentação escolar e criar condições para que sejam respeitadas as peculiaridades alimentares dos bebês e das crianças pequenas, proporcionando ambiente adequado à amamentação e ao preparo dos alimentos.

Fica sob a responsabilidade do Governo fiscalizar que as instituições garantam uma alimentação adequada, respeitando as necessidades alimentares das crianças, além de orientar as escolas para que realizem um trabalho que visa o desenvolvimento integral da criança junto à participação da família, tornando essa relação triangular família-criança-escola.

A partir disso, reconhecendo a criança como ser que aprende e que necessita de cuidados, o Currículo em Movimento da Educação Básica do Distrito Federal, estabelece preceitos básicos para cada faixa etária a fim de contribuir para a melhoria da educação. Diante disso, é descrito alguns princípios que devem ser 
cumpridos pelas escolas do DF, no qual no tópico "2.2 Bebês e crianças pequenas o que podemos considerar?" (p.26), deixa claro que para lidar com seres humanos é necessário entender a dependência da relação cotidiana familiar e seu peso cultural, a influência da instituição escolar na vida da criança, a maneira como aprendem e o desenvolvimento físico, emocional, cognitivo e motor que envolvem cada um.

Dessa maneira, o Currículo quando se refere à alimentação, traz que o cuidar e o educar estão sempre juntos na Educação Infantil, pois norteiam as crianças sobre a importância da alimentação, a necessidade de comer frutas e verduras, a utilização dos talheres e a mastigação correta, além, de alertar sobre os hábitos de higiene, boas maneiras e os cuidados que devem ter com o desperdiço de alimentos entre outros. É então fundamental que o momento separado para a refeição não se torne um período automático ou que gere estresse a criança, e para isso são estabelecidas algumas observações:

- O ambiente onde as crianças fazem as refeições deve estar em boas condições de higiene, ser seguro, confortável, com condições de independência e socialização;

- os alimentos devem ser servidos em temperatura adequada para serem ingeridos pela criança.

- as crianças maiores devem ser incentivadas a servirem o seu próprio prato, com o apoio do adulto, e a mastigar bem os alimentos;

- A alimentação deve atender às necessidades nutricionais das crianças de diferentes idades;

- as crianças devem ser estimuladas a apreciar os sabores, as cores, as texturas e a consistência de diferentes alimentos;

- as crianças que recusam alimentos ou que apresentam dificuldades para se alimentarem sozinhas devem merecer maior atenção;

- é preciso disponibilizar água potável e utensílios limpos individualizados para as crianças beberem água durante todo o dia; (SEDF, 2013, p. 60)

É importante destacar que tanto o Plano Distrital de Educação quanto o Currículo em Movimento, tratam a alimentação em sua totalidade como uma situação principalmente biológica, visando o bem-estar da criança, criando ambientes favoráveis à sua alimentação. No entanto, parece não considerar os aspectos que envolvem a construção de identidade e organização de formas de relação com o mundo, evolução cognitiva, afetiva, social e pedagógica que ocorrem durante a refeição. Deve ser destacado que a alimentação envolve muitas etapas da construção do sujeito e devem ter uma notoriedade maior por parte do governo, 
professores e responsáveis. Sendo assim, é necessário que exista um preparo dos profissionais para saberem suscitar nas crianças contextos que lhes permitam explorar e se reconhecer em situações que surgem durante esses momentos. Assim, é importante que se facilite a criação de dinâmicas semióticas que despertem a curiosidade, diálogos e propicie outras camadas afetivas e relacionais dos processos de desenvolvimento da criança.

A autonomia, segundo o Currículo tem por finalidade tornar a criança consciente de suas ações, mas para que isso ocorra, é necessária a presença de um mediador, para que possa orientar, observar, incentivar, instigar e participar desse momento de exploração. Visando o bem-estar da criança, o trabalho desenvolvido pela escola deve ser acompanhado e complementado pela família em seu lar, a fim de incentivar e contribuir para o prosseguimento das vivencias e do contato com a novidade, valorizando e reforçando os momentos da alimentação e higienização além de demonstrar a importância de cada um desses para o desenvolvimento da criança. A autonomia não é em seu sentido absoluto, está associada à possibilidade de exploração do corpo, dos sentidos, das sensações, emoções e do modo como vivenciam a cultura. Na Educação Infantil, o desenvolvimento da criança deve ser canalizado para o conhecimento das práticas, saberes, emoções, afetos e sentimentos que envolvem também o uso dos objetos e da exploração degustativa. Essas ações deverão permitir a significação e construção dos sentidos (na experiência fenomenológica) que poderão ser à base da construção de si mesmo e do posicionamento dele na cultura.

\subsection{A criança e os objetos nos processos de alimentação}

Quando falamos de objeto, falamos das convenções culturais e regras de uso que cada um dos utensílios possui. De acordo com Rodriguez e Moro (1999, p. 86) para que a criança consiga se apropriar dos objetos sociais, ela deve interagir com as pessoas que também são sociais, pois os objetos que construímos historicamente possuem uma compreensão coletiva, têm funções e significados particulares e contextualmente restritos, além de poder ser usados de forma adequada ou não, com interpretações e objetivos diferentes, logo, o objeto faz parte das redes e dos 
usos culturais, e seu significado ultrapassa os usos idiossincrásicos que os sujeitos fazem dele.No entanto, os objetos além de permitir um uso não canônico, possibilitam os usos simbólicos. Um lápis, por exemplo, pode ser usado tanto para escrever quanto para imitar um martelo (significado simbólico), dessa forma a criança utiliza duas realidades sequenciais. A criança pode usar o objeto como quer, ou como deve ser usado, ou seja, cada um desses momentos está acompanhado da apropriação dos aspectos convencionais, das significações e de infinitas possibilidades co-construidas pela cultura ao longo dos processos de desenvolvimento.

Não se acham, portanto, no exterior da cultura, nem à margem da comunicação, possuem significados públicos que as crianças adquirem como consequência de muita semiose em situações de interação com os outros que as foram configurando. (RODRIGUEZ, 2009, p. 202)

Dessa forma as ações com os objetos vão sendo modificados de acordo com os processos de semiose nos relacionamentos com outros. A semiose é o processo de produção de significados e sentidos ao longo das experiências ontogenéticas compartilhadas socialmente. Portanto, a partir do momento em que a criança se apropria das ações intencionais compartilhadas cotidianamente pelo e com o adulto,começa a reconhecer, nessas ações, os usos convencionais. Dessa forma, a criança utiliza o objeto da maneira canônica e compreende o uso convencional. É ao longo desse processo relacional e de semiose que a criança compreende a diferença entre o uso do objeto simbólico e do convencional.

Quando as crianças começam a usar os objetos de modo convencional, significa que se impregnam um sentido que não é individual, mas compartilhado pelo grupo, dotados de direção; é assim que as condutas intencionais - a intencionalidade em Piaget se articula com as condições do aparecimento das primeiras condutas inteligentes - são inseridas em redes públicas. (RODRÍGUEZ, 2009, p. 235)

Ainda segundo Rodriguez, o contato da criança com o objeto convencional torna-se mais expressivo aos sete meses, quando começa a utilizá-lo com mais frequência, "até os oito ou nove meses, o bebê começa a se situar em um universo independente dele" (Piaget, 1936, p.188 apud Rodríguez) assim como afirma a teoria de Piaget, a partir do subestágio 3 (4 a 8 meses), a criança passa a perceber 
uma dinâmica diferente, então foca suas ações no externo para entender novas informações em relação ao mundo, não apenas no objeto, mas também no resultado de suas ações. Assim sendo, a criança torna-se insatisfeita com o que recebe e procura realizar suas próprias experiências e, então, passa a tomar iniciativa de realizar o uso convencional do objeto. Nessa fase a criança ainda não possui total autonomia de locomoção e controle de suas funções motoras, tais experiências dependem da ação do outro, assim, a criança convida o adulto para que participe.

RODRIGUEZ (2009) destaca que "seria impossível pensar que as crianças fossem capazes de adentrar nos usos simbólicos se eles estivessem completamente ausentes do repertório cultural das condutas dos adultos que a cercam" ( $p$. 243).Portanto, o adulto se torna a primeira referência da criança, na utilização dos objetos de maneira simbólica e convencional. Tais situações ocorrem em condições não convencionais, em grande maioria, durante as brincadeiras. É importante frisar que para a criança realizar ações simbólicas, é preciso ter se apropriado do uso convencional anteriormente, pois não fazem cópias da ação do outro, mas firmam os seus usos complexos como resultado da comunicação com outras pessoas.

\footnotetext{
Portanto, os símbolos apoiam-se em sistemas semióticos que a criança já tem construído previamente, cujas regras são públicas e graças às quais os objetos começam a ser usados e compreendidos a partir das suas propriedades sociais e convencionais. (RODRÍGUEZ e MORO, 2002, p. 324)
}

Salientamos aqui, o desenvolvimento do ser humano feito de forma constante, ao longo de sua vida, conhecendo novas culturas, usos, objetos e aprendizados. Dessa forma, a criança aprende e entende que em nossa cultura, usamos os talheres durante a alimentação, e na cultura oriental utilizam com mais frequência o hashi, assim como em outros lugares utiliza-se a mão para se alimentar. Diante disso, reforçamos que os objetos são construções culturais, que variam entre regiões e nações, e a apropriação de novos recursos requer o conhecimento convencional sobre cada objeto. Dessa forma, podemos comprovar que os objetos têm motivações e intenções de acordo com a intencionalidade imposta pela pessoa que o está usando.

\subsection{0 relacionamento no aspecto semiótico e a triadicidade}


Ao nascer o universo da criança se encontra direcionado ao reflexo da alimentação/sucção que ocorre através do contato com a mãe em um movimento de repetição. É nessa fase que ocorre a primeira relação semiótica do bebê, No qual de forma - até então - não intencional vai criando signos que vão sendo interpretados pelos pais, ou seja, a criança chora quando está com fome e a mãe ao reconhecer a necessidade do bebê o amamenta. Dessa forma funciona com os diferentes choros produzidos por dor, incomodo e sono. Segundo ESPAÑOL(2004, p.11)

\footnotetext{
"Simplesmente, na díade mãe-bebê, se produz uma interação na qual o recém-nascido, sem ter consciência do que ocorre, consegue regular a conduta da mãe.E a mãe ao conceder sentido e intenção ao signo que recebe de seu filho, cria o cenário propício para que se desenvolva a capacidade de gerar intencionadamente signos".
}

A partir das seis semanas de vida, o bebê começa a se expressar através do rosto e de seu olhar em resposta às ações dos adultos, e a se interessar pelos objetos encontrados em seu meio. Visto isso, o sorriso expresso pela criança, é um reflexo da expressão de felicidade que foi fornecida da mãe, assim como quando a responsável muda sua expressão, a resposta visual da criança se modifica.

Ainda no aspecto da semiótica, Peirce abrange tanto o significado do signo quanto dos aspectos envolvendo as ações, pois fornece em sua teoria dois significados para o objeto, um que pode ser chamado de objeto concreto e outro que podemos caracterizar como imaginário. Durante essas fases, a criança passa por um momento importante no desenvolvimento, pois deixa de criar signos não intencionais e passa a elaborar signos com intenção comunicativa para os outros, de forma que começa a utilizar a comunicação pré-verbal.

Os gestos são uma dobra entre as duas pontas do desenvolvimento semiótico, é uma maneira que o bebê utiliza para se comunicar e expressar suas vontades, a criança pequena por volta dos oito meses compreende que suas ações geram um resultado, diferentemente do choro, essa é uma ação com intenção, visto que em sua maioria, a criança realiza essa interação direcionada ao adulto. ESPAÑOL (2004) confirma que "os gestos são signos nos quais se encontra uma clara intenção comunicativa".A criança fornece um signo, que é produto de processos de internalização (ex: esticar os braços para ser pego), e o adulto interpreta essa ação dando o significado que a criança procurava (pega o bebê no 
colo). A comunicação emocional da díade "criança-adulto" cede lugar a indireta tríade "criança-objeto-adulto", e passa a ter um cunho de construção de significado, afetividade e relações psicológicas. O que pode ser denominado por Piaget como inteligência sensório-motora, que é uma inteligência anterior a linguagem e ocorre até mais ou menos os dois anos de idade. As ações intencionadas são realizadas para serem facilmente interpretadas. ESPAÑOL (2004) relata que "as ações intencionadas não têm uma intenção comunicativa, elas são resultado da combinação de esquemas de ação".

[...] a consciência começa por um egocentrismo inconsciente e integral, até que os progressos da inteligência sensório motora levem a construção de um universo objetivo, onde o próprio corpo aparece como elemento. (PIAGET, 1964, p.19 apud RAPPAPORT, 2005. Vol. 1, p.66).

De acordo com RODRÍGUEZ (2009, p. 172), a intencionalidade comunicativa representa um avanço muito importante no desenvolvimento infantil, no qual se dá início a um triângulo comunicativo entre a criança, o objeto e o adulto, o que chamamos de triadicidade. A mãe ao oferecer o leite materno, chupeta ou mamadeira, vai contribuindo para as situações em que a criança aprende, diferencia e interage. Dessa forma, a criança passa por uma série de construções culturais que serão essenciais para seu desenvolvimento, antes da função e uso convencional dos objetos. A autora destaca que o primeiro ato dessa triangulação começa no nascimento com a alimentação, em que é necessária a presença de um objeto, do interpretante e do objetivo.

Da mesma forma, ESPAÑOL (2004), exemplifica a triangulação da seguinte maneira: "[...] as crianças realizam ações sobre os objetos dirigidas aos outros, como trazer um objeto ao adulto ou pegar um objeto que ele oferece. Essas ações são denominadas ações triádicas". Assim, a criança quando se depara com um objeto que não conhece ou que não possui uso convencional, inicialmente mexe naquele utensílio de forma arbitrária, sem muita orientação, até que observa o interpretante, a fim de descobrir quais funções dispõe aquele instrumento. Após analisar e observar, o bebê refaz as ações de forma similar a sequência do adulto. 
vai incorporando a gramática da ação que fica encoberto a ele. (ESPAÑOL, 2005, p. 142)

Portanto, na tríade o adulto possui um papel crucial no desenvolvimento dessas ações, visto que a primeira referência da criança são seus responsáveis, e toda ação realizada pelos mesmos, serão reflexos dos ensinamentos aprendidos. A bagagem cultural sobre os usos dos objetos convencionais, depende da estrita relação entre pares, da mesma forma funciona com os usos simbólicos dos objetos, pois um não coexiste sem o outro, são interações de troca e aprendizado. Sendo assim, toda ação com o objeto, seja ela externa ou interiorizada, depende da intencionalidade da pessoa que o está usando.

\subsection{Os objetos na alimentação}

Durante o período de desenvolvimento, os adultos utilizam de várias estratégias para eliminar possíveis barreiras de restrições motoras de suas crianças, realizando assim diversas atividades, que incentivem sua articulação e firmeza. Assim acontece quando a criança ainda não desenvolveu completamente sua coordenação em agir sozinha. As interações sociais, os processos de desenvolvimento, e o constante uso permitem as crianças que se apropriem de forma concreta dos objetos, de forma que em determinado momento, será capaz de executar tais ações sem ajuda de seu responsável.

Como citado nos subtítulos anteriores, a criança explora o objeto mesmo depois de conhecer sua função convencional, pois, fazem usos simbólicos para que os objetos tenham funções diferentes das culturais. Sendo assim, podem alternar entre utilizar o uso simbólico ou convencional, sem prejudicar seu entendimento sobre os objetos, como por exemplo, usar uma vasilha como chapéu, ou uma banana como telefone, por volta de um ano, as crianças já usam a colher para brincar de dar de comer a bonecas, simulando situações que passam em seu cotidiano, compartilhando um conhecimento social e cultural.

Os seres humanos preparam, utilizam e comem as refeições com o auxílio de utensílios de mesa e mantém os alimentos em recipientes para que fiquem conservados. Culturalmente, alguns alimentos não são diretamente plantados e dispostos a mesa, antes, passa por diversos processos até chegarem as casas, que 
em seguida são preparados de acordo com o cardápio estipulado no dia. A cozinha é uma das primeiras e mais sofisticadas tecnologias desenvolvidas pela espécie. Ela não aponta apenas para garantir processos básicos de supervivência, mas também para facilitar ritos, símbolos, práticas e saberes constituídos ao longo da organização semiótico-cultural dos grupos humanos.

De acordo com ISHIGURO (2014), as crianças são capazes de aprender com um ambiente/espaço comunicativo, compartilhado e mutuamente disponível entre os participantes em que falam e compartilham conhecimento, podendo adquirir meios para viver uma vida saudável. Dessa maneira, o comportamento da família em casa, das educadoras na escola, por meio da fala, postura e alimentação podem influenciar no comportamento das crianças, pois estas tendem a reproduzir costumes e hábitos aprendidos. A nutrição adequada nos primeiros anos de vida é fundamental para o crescimento e o desenvolvimento saudável das crianças. A infância é o período de formação dos hábitos alimentares, e estes desempenham diferentes funções no nosso organismo, fornece energia, proteínas, vitaminas e minerais que ajudam no metabolismo. Sendo assim, o alimento faz parte da interação entre a tríade, ele tem função própria, devido às funções que assume na alimentação.

\footnotetext{
A formação de hábitos alimentares saudáveis é um processo que se inicia desde o nascimento, com as práticas alimentares introduzidas nos primeiros anos de vida pelos pais, primeiros responsáveis pela formação dos mesmos. (AMARAL, 2008, p. 01).
}

Este trabalho tem por objetivo analisar as ações, diálogos e posicionamentos em contexto presente no uso dos objetos na perspectiva triádica expressas ao longo dos onze dias de observações, em situações de alimentações com duas crianças (Rosa e Íris) no contexto escolar. Sendo caracterizados os momentos da rotina, comportamentos e ações pedagógicas que promoveram ou restringiram o uso convencional e autônomo dos objetos partindo da iniciativa dada pelas monitoras responsáveis para e com as crianças. Serão descritos os objetos presentes, os usos realizados por parte das crianças durante a alimentação e identificadas as formas de interação da tríade criança-objeto-adulto. 
As análises serão feitas com base nas observações realizadas na creche e de acordo com o respaldo teórico pesquisado, a fim de compreender as ações pedagógicas e mediações que ocorrem durante as refeições com relações aos objetos. 


\section{ASPECTOS METODOLÓGICOS}

Os processos metodológicos são construções que não seguem um roteiro específico durante a pesquisa. Dessa forma, em cada projeto, novas adaptações e reorganizações podem surgir como formas de estruturação dos dados e das análises e interpretações dos resultados.

$\mathrm{Na}$ pesquisa com crianças em contexto escolar, a observação é uma ferramenta importante no que tange aos processos de identificação de processos relacionais e de aprendizagem/ensino. As análises microgenéticas, observações e intervenções específicas em contextos particulares e com ênfase nas ações e diálogos singulares, se convertem em formas de compreender a realidade de forma ampla e ao mesmo tempo complexa. As análises microgenéticas permitem molecularizar os aspectos menos evidentes, mais sutis e densos sobre os significados, emoções e ações envolvidas. Pode-se afirmar que a abordagem microgenética faz parte de uma pesquisa sociocultural, assim como declara Wertsch (1998a, p. 56), "[...] entender a relação entre o funcionamento mental humano, por um lado, e o contexto cultural, histórico e institucional, por outro". Dessa forma, a pesquisa não se baseia exclusivamente no conteúdo das falas que se relacionam no processo da comunicação, mas nas expressões, no movimento dos participantes e na forma como demonstram seus pensamentos e suas ações.

Tendo em vista que o processo comunicativo possui dois objetivos funcionais complementares e distintos, no qual o primeiro pode ser classificado como a comunicação do conteúdo, que ocorre quando a informação é veiculada entre os indivíduos e, o segundo é a comunicação dos indicadores, quando há regras necessárias na interpretação do conteúdo, podendo alterar a mensagem. Assim, a comunicação ocorre através de canais múltiplos, na qual refletem as diferentes dimensões do fenômeno expressivo, resultando na co-construção da mistura semiótica, que abrange os participantes da experiência comunicativa.

Podemos então entender que a comunicação dos conteúdos se dá de uma maneira explicita e elaborada pela linguagem convencional, podendo ser verbal ou por meio da gestualização simbólica, feita por pessoas de uma mesma cultura. $O$ termo "dialógico" designa esta forma comunicativa, que possui natureza linguística. 
Já a comunicação analógica representaria a modalidade metacomunicativa, no qual é feito o uso de recursos não verbais, tais como posturas, entonação vocal, expressões faciais e corporais, e assim por diante.

Na realização dessa pesquisa, foi utilizada a abordagem nas ações e diálogos que emergem nos momentos de interação entre os adultos e as crianças, no qual pretendem analisar os significados, posicionamentos, processos metacomunicativos e práticas, de forma a aprofundar os resultados, visando uma interpretação sobre o tema abordado.

Antes de prosseguir, é necessário relembrar a diferença entre a comunicação dialógica e a metacomunicação. Na comunicação dialógica a comunicação ocorre entre indivíduos de maneira episódica, quando há engajamento por trocas linguísticas de qualquer natureza. Já a metacomunicação, é um processo utilizado na realização desta pesquisa, ocorre de maneira fluída e continuamente ao nível não-verbal, através de múltiplos canais da expressividade humana, ou seja, as expressões faciais, olhar, toque, postura, ritmo e entonação de fala e movimento corporal, assim como destaca BRANCO (1996) em seu artigo.

Utilizaremos a estratégia do Estudo de Caso, que tem por objetivo explorar com profundidade um processo, nesse caso, os processos de alimentação na Educação Infantil: Estudo de caso sobre a prática no ambiente escolar com crianças de três anos.

Foi definido como procedimentos, a utilização de observações em sala de aula, gravações de áudio e vídeo, fotos e registros escritos. O resultado da pesquisa foi estabelecido a partir dos registros das situações no ambiente escolar, assim, como a análise dos dados coletados.

Nesse projeto, as observações iniciais que pretendiam analisar 0 funcionamento e rotina da alimentação das crianças foram realizadas primeiramente, e a partir disso, foram identificados diálogos, entonações e ações que contribuem para o objetivo da pesquisa. Diante dessa observação foram estabelecidos dois casos relevantes para o andamento do projeto. O primeiro se refere a criança 'Íris' que tem dificuldades para se alimentar sozinha e espera pela iniciativa das monitoras. E o segundo caso é referente à criança 'Rosa' que come sozinha, sem dificuldades ou necessidade de ajuda. 
A pesquisa foi realizada de forma consecutiva na escola, apenas sendo alternados os horários, a fim de observar a diferença de reações no uso dos objetos de acordo com as refeições. A pesquisa foi realizada da seguinte forma no ambiente escolar:

- Uma sessão para conhecer o ambiente;

- Nove sessões para observar as crianças durante as refeições;

- Dois dias para as entrevistas;

Totalizando 11 dias de análise. Visto isso, foi dada atenção às duas principais refeições do dia, o almoço e o jantar. Na oitava e décima primeira sessão foi realizada as entrevistas com as duas monitoras de sala e a nutricionista, que se encontra no apêndice A. As observações foram gravadas e transcritas para análise.

Cada observação teve a duração de 30 minutos, totalizando 4 horas de analise, 2 horas de entrevistas e 1 hora para conhecer a escola. Sendo selecionados posteriormente recortes que totalizaram 2 horas para utilização na pesquisa. As entrevistas foram realizadas em dois dias distintos para não modificar a rotina de trabalho das profissionais, e teve como intuito a complementação das observações, e a fundamento de entendimento sobre o trabalho prático realizado e o teórico passado para as profissionais.

As divisões da observação nesses períodos específicos pretendem ampliar o número de encontros e identificar ações específicas em situações particulares. Em cada uma das sessões foram destacadas, pelo menos 1 situação que permitia dar conta dos interesses e objetivos da pesquisa. Como forma de apresentar os registros, as observações foram organizadas em cenas, fragmentos e turnos. Em cada cena foram identificados turnos ${ }^{1}$ que correspondem as falas e/ou ações expressas pelas crianças ou pelas monitoras. As transcrições apresentadas foram consideradas chaves para a evolução dessa pesquisa.

\footnotetext{
${ }^{1}$ Turnos: Utilizado para indicar troca de sequência e/ou vez de fala
} 
Tabela 1- Observações na creche

\begin{tabular}{|c|c|c|}
\hline 1 Sessão & Conhecer a escola & 1 hora \\
\hline 20 Sessão & Observação da janta & 30 minutos \\
\hline 3 Sessão & Observação da janta & 30 minutos \\
\hline 4 Sessão & Observação do almoço & 30 minutos \\
\hline 5 Sessão & Observação da janta & 30 minutos \\
\hline 60 Sessão & Observação da janta & 30 minutos \\
\hline $7^{0}$ Sessão & Observação da janta & 30 minutos \\
\hline 8ㅇ Dia & Entrevista Nutricionista & 1 hora \\
\hline 9 Sessão & Observação da janta & 30 minutos \\
\hline $10^{\circ}$ Sessão & Observação do almoço & 30 minutos \\
\hline $11^{\circ} \mathrm{Dia}$ & Entrevista Monitoras & 1 hora \\
\hline
\end{tabular}

Para realizar o processo de análise dessa pesquisa, estabelecemos relações entre as situações que surgiram na creche, com foco em dois casos específicos. Dessa forma, criamos uma explanação entre as 2 situações, pretendemos destacar os momentos de falas (existentes e inexistentes), práticas e ações que favorecem ou não os processos de desenvolvimento da criança com os objetos. Analisaremos também como as monitoras se posicionam diante das situações em que se encontram. Inicialmente cada observação e entrevista foram realizadas e analisadas separadamente, para só então, ser realizada a análise geral do processo. Destaco que durante as observações no refeitório a professora não estava presente.

Os nomes reais foram substituídos por fictícios, a fim de não identificar os sujeitos da pesquisa. Usaremos nomes de flores para identificar os participantes.

\section{Tabela 2 - Participantes da pesquisa}

\begin{tabular}{|c|c|}
\hline Monitoras & Crianças \\
\hline Duas monitoras & \\
M1: Superior cursando & Quinze crianças. \\
M2: Ensino Médio Completo & 2 a 3 anos \\
\hline
\end{tabular}




\section{ANÁLISE E RESULTADOS}

Contextualização da escola pesquisada

A creche escolhida funciona em tempo integral e atende crianças em maior número de famílias de classe média baixa, cujos pais moram em regiões administrativas do entorno de Brasília e trabalham no mesmo setor da Creche. Sendo oferecidas cinco refeições diárias, além das noções de higiene pessoal e conhecimentos pedagógicos. A turma foi determinada de acordo com o critério de idade, entre dois e três anos, a fim de observar a importância do trabalho pedagógico durante as refeições, assim como a mediação feita pelas professoras no uso dos objetos.

A instituição possui 38 funcionários, sendo nove professores e 18 monitoras, com oito salas para atividades. E dispõe de cinco refeições diárias variadas as faixas etárias, compreendendo: café da manhã, lanche matinal, almoço, lanche vespertino e jantar. A turma citada acima possui 15 crianças com idade entre dois anos a três anos, e dispõe de uma professora regente e duas monitoras fixas, que acompanham as crianças durante o dia e nas refeições. De acordo com o PPP (Projeto Político Pedagógico) da instituição, as monitoras participam de formação continuada uma vez por semana, no qual é trabalhado o Currículo em Movimento da Educação Básica.

Ainda de acordo com o documento, a instituição exerce um papel facilitador na formação do hábito alimentar, além de promover a educação nutricional. Tem como um dos objetivos acompanhar o crescimento e o desenvolvimento das crianças, contribuindo para a formação de hábitos alimentares.

Sendo assim, a creche possui quatro projetos como complemento dos objetivos educacionais, que são:

- Projeto alimentação saudável: O objetivo é incentivar os bons hábitos alimentares, promover o consumo de alimentos saudáveis, valorizar o momento da refeição e desenvolver o conceito de quantidade, cores e formas. 
- Cozinha experimental: Trabalhar a percepção degustativa, desenvolver a coordenação motora e o trabalho em equipe, além de, ampliar o vocabulário.

- Almoço temático: Promover a degustação da gastronomia das regiões brasileiras.

- Projeto self-service: Favorecer e desenvolver a autonomia e o interesse das crianças e suas necessidades de escolhas.

Visto isso, a escola utiliza de diversos projetos, como um incentivo ao desenvolvimento integral da criança, de acordo com as leis que regem a educação infantil no Brasil. Visando sempre a participação da família, dos docentes, e dos alunos para a manutenção e criação desses projetos. O self-service foi observado durante o momento do almoço das crianças de três anos, visto que no jantar não consta essa opção por questão de segurança, pois costuma ser sopa, segundo a própria nutricionista da creche. No próximo tópico começaremos com a análise das observações na instituição.

A seguir, apresentaremos as cenas observadas em forma de descrição, a partir dos registros feitos durante a semana na creche escolhida. 


\subsection{Observação da escola}

Nesse tópico, apresentaremos a descrição da rotina escolar antes/após as refeições. Seguida da descrição e análise das cenas observadas no almoço e jantar com as crianças "Íris e Rosa".

\section{Descrição da rotina escolar do almoço e pós}

Todo dia o almoço é servido na organização de self-service, no qual cada criança, com orientação das monitoras é direcionada a colocar sua comida sozinha no prato, com uma quantidade orientada pelas responsáveis. Quando já estão no sentadas no refeitório, a monitora 1 chama as crianças pelo nome, de um em um para poderem se servir. Em cada ponta da mesa de comida, tem uma monitora para ajudar.

De acordo com a comida que tem na bandeja, são dispostas colheres especificas, no feijão tinha a concha, no arroz e na omelete de milho tinham duas colheres comuns e na salada havia um pegador. As crianças são chamadas de forma aleatória, independentemente do local onde sentaram. De acordo com o que as crianças vão se servindo a Monitora vai dispondo os pratos na pequena mesa.

Seguiremos com a cena 1 do almoço (Observação 4ํia)

Fragmento da cena 1 - caso Íris

1 "A monitora 1 chama a aluna Íris, que ao chegar na bancada, logo recebe seu prato (nesse momento a criança estica os braços para pegar o utensílio, mas a monitora antecipa o movimento da criança). "

2 "Íris pega a colher de arroz para começar a se servir, com certo esforço consegue dispor a comida no prato e em um breve momento "parte" o arroz, enquanto outra criança se aproxima para se servir."

3 "Ao notar que a criança tenta pegar outra colher de arroz de uma parte afastada da cuba, a M1 segura na mão da criança, auxiliando que ela 
pegue mais uma porção (fazendo assim a fila andar mais rápido), e logo afasta o prato de Íris para a próxima cuba."

4 "Na segunda cuba tem o feijão com a concha, com uma pequena dificuldade Íris levanta o utensílio, tentando levá-lo ao prato, novamente a M1 ao notar a dificuldade, segura na mão da criança e leva o feijão até o prato."

5 "Íris vai para a terceira bandeja, onde tem a omelete de milho, usando a colher, a criança se serve com um pedaço e leva o prato para as bandejas de verduras, no qual com a colher pega as aboboras, e com o pegador serve a acelga."

6 "Ao terminar, Íris se dirige a mesa para comer."

7 "Sentada na mesa com os colegas, Íris pega o pedaço inteiro de omelete com a colher e leva a boca, inclinando a cabeça para frente, enquanto mastiga observa as crianças ao seu redor, a monitora se aproxima e pega a colher de Íris para partir em pedaços sua omelete, após esperar, Íris volta a comer."

8 "Próximo aos amigos, Íris come sozinha, sempre olhando os que estão a sua volta. Íris começa a se sacudir na cadeira e logo para de comer"

9 "Íris começa a encarar o prato, mexe a língua e espanta alguns insetos"

10 "Ao notar que íris parou de comer, a monitora retira seu prato e joga o resto no lixo, com isso, encaminha a criança para a sala."

Logo no turno 1 notamos que a monitora chama a criança para que possa se servir, mas antes que a criança tenha alguma reação, a responsável já antecipa os seus movimentos e entrega o prato em suas mãos, inibindo já o primeiro contato direto da menina com o objeto. Nos turnos 2 e 3 é possível observar que Íris coloca o alimento em seu prato e "parte" o arroz, para que não fique grande, analisando assim, a facilidade da criança para utilizar aquele utensílio. Mesmo com a iniciativa da criança em colocar mais comida, a monitora ao notar que ela possui dificuldade em alcançar a parte mais funda cuba (por ser mais baixa) novamente antecipa 0 movimento de Íris, segura em sua mão, pega a porção de arroz e afasta o prato da menina. Já no turno 4 , a dificuldade da criança se repete novamente pela altura em relação a cuba disposta, mas mesmo com esse empecilho a criança consegue 
levantar a concha do feijão, porém de forma repetida a monitora segura a mão de Íris e conduz o feijão até o prato da menina. Nos turnos 5 e 6, Íris se dirige a terceira bandeja, onde está a omelete de milho, se serve com um pedaço e leva o prato para a última cuba, onde está o pegador e sem dificuldades coloca as acelgas em seu prato. Ao terminar, a criança se dirige a mesa para comer, senta com seus colegas, inclina a cabeça, pega a omelete inteira e enquanto mastiga observa as pessoas ao seu redor assim como descrito no turno 7. No turno 8, a monitora passa na mesa, pega a colher de íris e parte em pedaços sua omelete, a criança então volta a comer sozinha sempre olhando os que estão a sua volta, mas em determinado momento começa a se mexer bastante e logo para de comer, encara o prato, mexe a língua e espanta alguns insetos, a criança aparenta estar desmotivada ou sem vontade de comer. Em nenhum momento a monitora aparece para alimentá-la na boca, podemos destacar essa situação também como um motivo para a criança parar de comer tão rapidamente, pois a mesma está acostumada a ser alimentada por uma das responsáveis, aqui temos um exemplo claro da metacomunicação, diante da postura da criança é possível observar a intenção de comunicação através de suas ações, que neste dia não houve troca por parte da monitora. Ao notar que Íris parou de comer, a monitora retira seu prato e joga o resto no lixo, com isso, encaminha a criança para a sala. "

Fragmento da Cena 1 - caso Rosa

Turnos

Fragmentos

1 "Vem Rosa" chama a monitora

2 "Ninguém senta no meu lugar!" Diz Rosa com a voz firma e alta enquanto mexe os braços.

3 "Vem Rosa, ninguém vai sentar aí não, vem logo" a monitora continua, enquanto a criança se aproxima da mesa.

4 "Rosa começa colocando o arroz com a colher, dando uma espiada para trás para ver se não tinha nenhum colega sentado em sua cadeira." 
5 "Logo, segue para o feijão. Segurando a concha com firmeza, Rosa leva o utensílio até seu prato, a monitora auxilia dando uns toques no objeto, e no final pega a concha da mão de Rosa e coloca de volta na cuba, sacudindo para não pingar. A monitora move o prato de Rosa para a próxima cuba, na qual está a omelete. "

6 "Rosa ao segurar a colher para pegar a omelete recebe ajuda da M1, que segura sua mão, pega o alimento e leva até o prato, novamente move o prato para a próxima cuba.

7 "Rosa segura a colher e com certa dificuldade tenta pegar a verdura que parece estar grudada uma na outra, a monitora que se encontra no final da mesa espera com paciência, e só após Rosa colocar a abóbora no prato, indica que aquela quantidade está adequada"

8 "Rosa utiliza o pegador, coloca as acelgas em seu prato e se dirige para sua mesa."

9 "Sentada na ponta da mesa, Rosa come sua comida, sempre observando os colegas."

10 "Com a colher começa a partir a abóbora e a omelete, e em um momento de descontração, pega um pedaço de acelga, levanta o braço e pergunta aos colegas "Quem quer, quem quer, quem quer?"

11 "A monitora olha com um ar de reprovação e sem entusiasmo diz: " $A$ Rosa quer". Diante da negativa da monitora, Rosa leva a acelga que segurava à boca."

12 "Rosa começa a mexer os braços e cantar, imitando um pássaro, junto com a colega que está ao seu lado, ao notar que parou de comer, a monitora retira seu prato da mesa."

13 "Rosa então levanta e é orientada a ir para sala, para poder escovar os dentes."

"Vem Rosa!" Inicia a monitora no turno 1. A criança que já sentada, ao ouvir seu nome, em forma de protesto levanta, se vira para os amigos e diz para não sentarem em seu lugar enquanto ela vai a bancada. Podemos destacar este turno como uma ação de pertencimento da criança no espaço, onde ela se reconhece e reconhece aquele objeto (cadeira) como dela. A monitora, parecendo pouco 
impaciente, responde para que a criança não se preocupe, pois ninguém vai sentar em seu lugar, assim como descrito nos turnos 2 e 3.

Nos turnos 4 e 5, ao chegar na cuba a criança coloca o arroz com a colher e dá uma espiada em sua mesa, para ver se não tinha ninguém em seu lugar, confirmando que não havia ninguém, Rosa se dirige a cuba do feijão, segura com firmeza a concha e guia o utensílio até seu prato, a monitora se aproxima e auxilia dando uns toques na colher que por fim retira o objeto de sua mão, coloca de volta a cuba, sacudindo para não pingar, e logo move o prato da criança até a cuba da omelete.

$\mathrm{Na}$ descrição dos turnos 6,7, 8 e 9, Rosa recebe ajuda da monitora que segura a sua mão, pega o alimento e leva o prato até a quarta cuba e em um movimento repetido move o prato da criança. Nesses turnos podemos destacar em primeiro momento a iniciativa da monitora de ajudar a criança, pois a colher utilizada era a convencional de sopa, ou seja, era um utensílio pequeno para a cuba usada. Rosa segura a colher e com certa dificuldade tenta pegar a verdura que parece estar grudada uma na outra, dessa vez, a monitora que se encontra no final da mesa espera com paciência, e só após Rosa colocar a abóbora no prato, indica que aquela quantidade está adequada, dessa forma, a criança vai para a próxima cuba, e com o pegador coloca as acelgas no prato, volta para o seu lugar na mesa e enquanto come observa seus colegas. Nesses turnos é possível observar que novamente quando se trata da colher de sopa, Rosa possui mais dificuldade, primeiro com a colher que não seria a mais adequada para aquele tamanho de cuba e segundo, pois o alimento está grudado, dificultando a movimentação da colher no interior do utensílio. Porém pode ser notado que neste momento a monitora que está no fim da mesa deixa que a criança explore sozinha, mesmo que possa demorar um pouco mais para que a menina tenha mais firmeza em seu movimento.

Nos turnos 10, 11 e 12 é importante destacar que a turma estava quieta enquanto almoçava, havia conversa apenas entre algumas crianças específicas, mas em baixo tom, dessa maneira como uma forma de chamar atenção, causar animação e demonstrar pertencimento, Rosa levanta sua mão com um pedaço de acelga e pergunta de forma bem espontânea aos colegas quem quer, repete três vezes até receber um olhar firme da monitora afirmando que quem quer é a própria 
criança, que logo ao notar que não recebeu a resposta esperada coloca a comida na boca.

Dessa maneira, nos turnos 13 e 14, a criança inicialmente começa a mexer os braços sozinha, até que sua colega ao lado acompanha seus movimentos e juntas começam a balançar os braços e as mãos imitando um pássaro e cantando baixinho, nesse instante a turma já se encontra mais descontraída, pois a maioria das crianças já estão terminando o almoço, logo, ao notar que já está satisfeita e consequentemente brincando com a comida, a monitora se aproxima, retira o prato de Rosa e pede que a criança vá para a sala para poder escovar os dentes. Nesse momento ao invés de apenas retirar o prato da mesa, a monitora poderia ter perguntado a Rosa se ela já estava terminando ou se já estava satisfeita, dando a criança o poder da palavra e da sua própria ação.

\section{Pós almoço}

Após o almoço, as crianças são conduzidas a sala. Quando chegam são chamados de dois em dois para entrar no banheiro, onde deverão escovar os dentes sob orientação das monitoras e professora. Após os dentes escovados, devem limpar a boca e mãos, tirar os sapatos e esperar na sala, enquanto a monitora está arrumando os colchões no qual irão dormir. Os itens de higiene reforçam mais ainda o aprendizado já adquirido pelas crianças durante a alimentação no refeitório, a participação das monitoras/professora nesse momento é muito necessária, pois ajudam a intensificar a importância de usar os objetos de forma adequada, medir quantidade de pasta, escovar corretamente os dentes, limpar as mãos e boca, tirar os sapatos antes de dormir, esperar o momento de entrar na sala do sono.

Após finalizar, a responsável vai chamando cada criança de acordo com o término da escovação, após deitados, as crianças são orientados a fechar os olhos, enquanto isso, a outra monitora começar a balançar algumas crianças, para ajudálos a pegar no sono mais rápido, e assim ocorre até que a última criança durma.

Análise do almoço

Primeiramente é muito importante destacar a importância da vivência e experiência das crianças com o self-service. Esta iniciativa da instituição é essencial 
para uma experiência e valorização completa do almoço, dos objetos e da alimentação, e não é uma pratica comum em crianças com tão pouca idade.

Durante as descrições pode-se observar que a monitora está preocupada com o tempo para chamar as crianças e agilizar o processo, dessa forma, sua ação em vários momentos se sobrepõe à autonomia das crianças. Deixando passar a oportunidade de explicar qual a melhor forma de pegar tal utensílio. Nas cenas apresentadas, é possível notar que existe uma variedade de comida posta as crianças, estas possuindo várias cores, gostos, texturas e pesos diferentes. Além da variedade de utensílios, entre eles o pegador, concha, pratos e talheres. Por sua vez, a monitora não explica nem auxilia a criança sobre a utilização desses objetos. Quando questionada sobre a existência de instrução sobre a alimentação com as monitoras, a nutricionista destacou que "É feito um treinamento, né, tanto no início do ano quanto no meio do ano, e ao longo desse período também, havendo alguma discordância, a gente, né, observando que elas estão procedendo de alguma forma que não seja correta, a gente intervêm também nas coordenações.".

É notória a diferença entre as crianças na hora de se servir, Íris possui mais dificuldades por ser uma criança baixa, uma das menores da turma. Já Rosa, tem estatura ideal para a mesa na qual estão as cubas, além de demonstrar ter mais firmeza na utilização dos objetos. Quando questionadas sobre as crianças utilizarem talheres e pratos sem dificuldade, a monitora respondeu que eles usam bem, " $a$ concha é um pouco mais complicada nos que são mais baixinhos, mas eles conseguem com certa dificuldade, mas conseguem por conta da altura, mas os outros eu acho que eles comem bem assim". Apesar da fala, não existe iniciativa para melhorar a situação das crianças menores, nem por parte das monitoras nem da escola, deveria ser dada uma atenção maior para essas necessidades, pois as experiências vivenciadas por essas crianças se tornam mais complicada e menos completa. Em outro trecho pergunto se já estão assim desde o início do ano ou se foi um trabalho progressivo, a monitora responde então: "eles sabiam utilizar, mas não pegavam de um jeito correto, a gente trabalhou pra eles usarem assim, para que não caísse da colher, não sujasse a mesa, mas foi uma coisa trabalhada." Diante dessa informação pode-se observar que mesmo com a afirmação de melhora no uso dos utensílios por parte das crianças, a quantidade de vezes que a monitora interfere na 
iniciativa das crianças ainda é muito significativa, como pode ser visto abaixo no gráfico individual detalhado de cada criança.

\section{FIGURA 1 - USO DOS OBJETOS}

- Caso Íris - Observação 4º dia

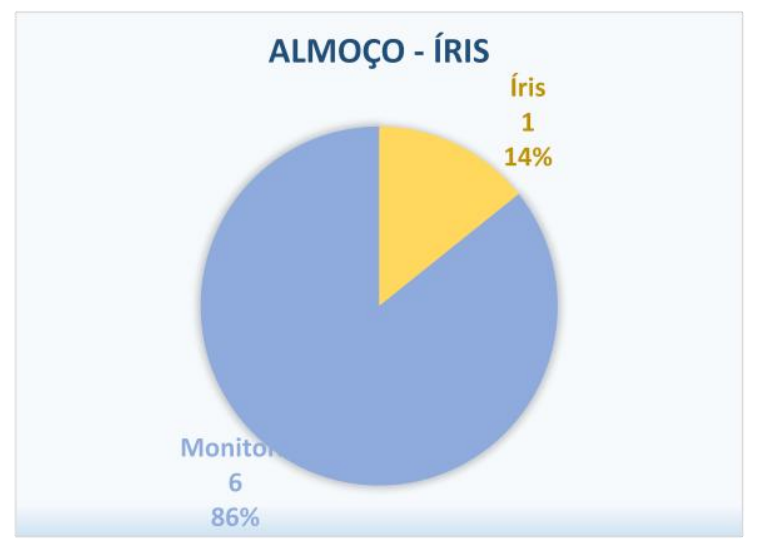

Quantidade de vezes que a criança utilizou o utensílio sozinha

Quantidade de vezes que a monitora pega o utensílio da criança

Fonte: autoral
- Caso Rosa - Observação 4º dia

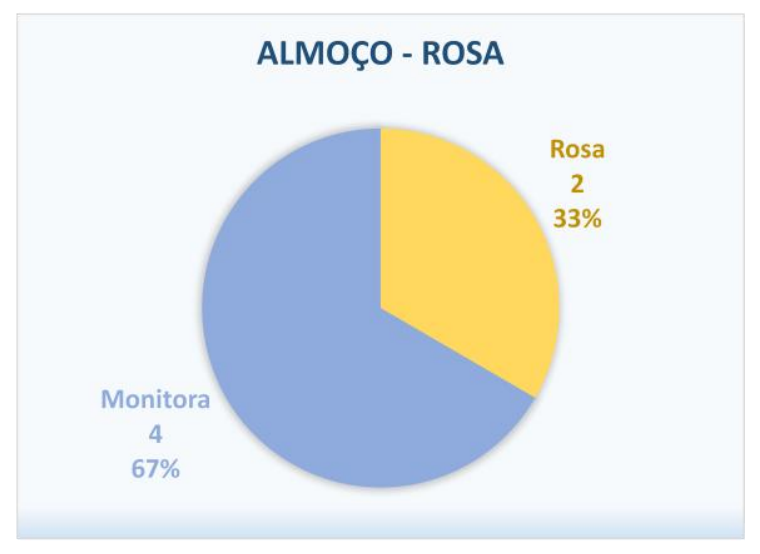

$\mathrm{Na}$ entrevista feita com as monitoras foi notado um desencontro de informações passadas pelas duas. No entanto, antes, precisamos reiterar a ideia já discutida na teoria de que os objetos possuem uma compreensão coletiva que possui funções e significados particulares e restritos. Assim, para que as crianças consigam se apropriar desses objetos sociais, elas devem partilhar os usos com outras pessoas, dessa forma as ações com os objetos vão sendo modificadas e construídas de acordo com os processos de semiose e significação nos relacionamentos com outros.

Quando perguntado sobre como/quando ocorre a explicação do uso dos objetos que é disposto para as crianças no refeitório a monitora 2 diz que não é feito no refeitório e sim na sala, onde falam sobre a alimentação e como deve ser feita. Já a monitora 1 diz não lembrar de terem explicado, mas acha que tal ação ocorreu no início do ano, logo quando eles começaram a se servir, e depois dessa vez não falaram mais sobre os utensílios. Logo, podemos afirmar que a explicação sobre os objetos ocorreu apenas no início do ano como falado pela monitora 1. Diante disso, podemos notar que existe uma divergência na fala das duas, e que durante as observações não foi constatado explicação sobre os utensílios na sala de aula, como dito pela monitora 2.É importante relembrar que de acordo com a proposta teórica já 
descrita, sabe-se que o objeto com uso convencional é aquele que a criança vê como os adultos usam e aprendem gradualmente. Portanto, na tríade o adulto tem o papel crucial no desenvolvimento dessas ações, visto que a primeira referência da criança são seus responsáveis.

Para que ocorra a semiose é necessário um processo de produção de significados e sentidos ao longo das experiências compartilhadas socialmente. Por isso devemos frisar que para que as crianças consigam se apropriar do uso convencional desses utensílios é importante a comunicação com outras pessoas, visto que, o adulto se torna a primeira referência da criança, na utilização dos objetos de maneira simbólica e convencional. Diante disso, foi observado que não existe muita comunicação com as crianças entre si e as monitoras, nos poucos momentos em que as meninas tentaram socializar, não houve retribuição da ação por parte das responsáveis, tal ação pode causar a inibição da espontaneidade social e exploração das crianças com os utensílios e novas funções que podem ser dadas a ele.

Descrição da rotina escolar antes da Janta

Durante a parte da tarde, as crianças permanecem apenas sob a responsabilidade das monitoras, visto que, a professora trabalha apenas no período da manhã. Diante de tal informação, seguiremos a observação separada por refeições e crianças, baseada no maior fluxo de relação das monitoras com os alunos.

Ainda em sala, antes da janta, as monitoras dão banho e arrumam as crianças, uma a uma, enquanto arrumam os cabelos, as crianças que já estão prontas ficam andando e brincando na sala livremente, enquanto as monitoras não terminam. Perto da hora de se dirigir ao refeitório, a monitora pede que as crianças arrumem suas mochilas, guardem os brinquedos e casacos (caso estejam usando).

"Já ta na hora da janta, vamos! Guarda os brinquedos na caixa que temos que sair, bora, bora, bora que a gente ta atrasado." Diz a monitora 1 para as crianças.

Em fila, acompanhados pelas monitoras, as crianças se dirigem as mesas, enquanto sentam, as responsáveis se dirigem à cozinha para pegar as cubas com a 
comida, pratos e talheres. Com todos sentados, as monitoras vão colocando a comida no prato e entregando a cada um, começando pelos que estão mais perto da mesa de servir. A turma costuma estar dividida em 2 ou 3 mesas, com 4 a 5 crianças dependendo do dia. Após todos com pratos e acomodados, as monitoras se direcionam as mesas de sua escolha, para auxiliarem as crianças que possuem mais dificuldades.

Seguiremos com as cenas 2 e 3 do jantar (Observações $2^{\circ}$ e $9^{\circ}$ dia)

Nos turnos das cenas apresentadas abaixo, teremos a descrição do jantar feita com as crianças escolhidas para a pesquisa, onde a monitora distribui os pratos com a comida para cada um, enquanto demanda sua atenção para quem não está comendo, como pode ser visto no texto a seguir.

Cena 2 do jantar (Observação $2^{\circ}$ dia)

Fragmentos da Cena 2 - caso Íris

\section{Turnos}

Fragmentos

1 "Íris escolhe uma mesa, se senta e recebe o prato que foi entregue pela monitora."

2 "Ao notar que Íris não está comendo, apenas olhando os colegas, M2 senta entre Íris e seu colega Cacto, para assim alimentar os dois."

3 "A monitora passa então a intercalar o alimento entre os dois, dando uma colherada para cada."

44 "Enquanto mastiga, Íris apenas observa os colegas que estão a sua volta. Logo a monitora se vira novamente para ela, enche a colher, apoia o cotovelo na cadeira, olha, espera ela terminar de mastigar e já direciona a colher para boca de Íris."

5 "Íris de início se recusa e balança a cabeça em sinal de 'não' se recusando a receber a nova colherada, mas a monitora diz: "Vamos, mais uma Íris", automaticamente a criança abre a boca e mastiga sem muito entusiasmo."

6 "Com a colher cheia novamente e o corpo direcionado para Íris, a M2 se vira rápido para chamar a atenção de Cacto e volta sua atenção para Íris." 
7 "Íris abaixa a cabeça para ver alguma coisa em baixo da mesa, logo a monitora toca em seu ombro e diz: "Bora Irisinha, quer que eu conte pro papai que você não está comendo?"

8 "Com um olhar de susto, Íris levanta o rosto e responde Não. "

9 "Então come" retruca a monitora, já levando a comida em direção a Íris que abre a boca. "

10 "A monitora já começa a raspar o prato enquanto Íris se vira para olhar os colegas, com a boca cheia, mas sem mastigar."

11 “Leva lá esses pratos aqui pra titia lá” diz a monitora para outra criança enquanto espera Íris mastigar. "

12 "Se virando novamente para Íris que está de costas, M2 toca seu ombro e diz: "Ei Írisinha, bora Íris, mastiga". Nesse momento a monitora começa a acariciar o cabelo da criança ainda esperando ela terminar de mastigar."

13 "Monitora corta o ultimo pedaço de carne, raspa o prato e leva a colher até Íris, que abre a boca."

No turno 1, Íris escolhe a mesa, recebe o prato e olha seus colegas, observando o que fazem, esperando que se sentem. Ainda com a mesma ação, a criança segura a colher esperando que alguém se aproxime para alimentá-la. Já no turno 2 e 3, seu colega Cacto que estava sentado na mesma mesa, também é ajudado pela monitora 2, mesmo ele estando comendo sozinho inicialmente, na qual ela intercala entre as crianças. Durante os turnos 4 e 5 de Íris, observamos novamente a pressa da monitora, pois durante uma mastigada e outra da menina, a responsável já está com a colher preparada e direcionada para alimentá-la novamente, mesmo diante da recusa da criança. No turno 7 a monitora usa da ameaça para que Íris se concentre na refeição, dizendo que irá chamar seus pais caso ela não coma. O que causa a reação de susto, e uma resposta de medo vindo da criança, como demonstra o turno 8. Sabendo que a semiose é um processo de produção de significados e sentidos ao longo das experiências compartilhadas socialmente e a triadicidade é a realização de ações sobre os objetos dirigida aos outros, podemos destacar que a ação realizada pela monitora, pode causar na criança reações adversas, assim como visto acima. Ao invés de instigar a curiosidade da menina ao alimento ou ao utensílio, usando de ideias e diálogos para 
explicar o quão importante é se sentar corretamente e usar os objetos, mostrando os alimentos que está sendo digerido ou os benefícios que aquele momento trás para a saúde, a responsável deixou a pressa se sobrepor ao conhecimento que poderia ter passado. Ou seja, a criança não realiza a ação com o objeto por vontade própria nem possui o intuito de exploração e conhecimento, sua ação é advinda do medo de ser chamada atenção por seu pai. A M2 então retruca e com firmeza diz para a criança que coma, Íris automaticamente abre a boca, mas notoriamente sem vontade de comer e fica com o alimento na boca (turnos 9 e 10), esse processo insistente pode causar na criança uma aversão a determinados alimentos e aos momento da alimentação, pois o período que seria de grandes descobertas e muito prazeroso se torna forçado e desvalorizado. A monitora no turno 12 cutuca o ombro de Íris pedindo que ela se apresse, que mastigue, e como uma forma de amenizar a ação começa a acariciar o cabelo da criança, mas no turno 13 já volta a sua ação automática de levar a comida até a boca de Íris.

Seguiremos com a cena 3 do jantar (Observação 9ºdia)

Fragmento da Cena 3 - caso Rosa

Turnos

Fragmentos

1 "Rosa recebe o prato de seu colega que hoje está ajudando a monitora, ao receber a comida, começa a observar as outras crianças, mas logo se ajeita na cadeira e volta sua direção ao prato."

2 "Rosa come com a colher enquanto observa os colegas, utilizando as mãos para auxiliá-la quando a comida cai um pouco para fora da boca".

3 "Rosa em alguns momentos se vira para olhar o que está em sua volta, mas sempre rapidamente volta a comer, na mesa com ela está dois colegas que também se alimentam sozinhos. "

4 "Rosa pega um pedaço de carne com a mão e leva a boca, em seguida bate a colher no prato para separar outro pedaço e novamente direciona a boca."

5 "Em determinado momento a criança começa a brincar com a colher na mesa, enquanto mastiga a comida que está na boca." 
6 "A monitora se aproxima apenas para acariciar a cabeça de Rosa e volta sua atenção as crianças das outras mesas."

7 "Em outro momento a M2 se aproxima e coloca a cadeira entre as mesas de Rosa e sua colega, mesmo vendo que criança está se alimentando sozinha, a monitora começa a dar a janta para Rosa, intercalando entre dar na boca e separar na colher a comida no prato, pois ela é uma das últimas que ainda está no refeitório. "

8 "Ei minha filha, ó, come, meu amor." M2 diz tocando o prato no braço de Rosa ao ver que ela está comendo distraída observando o que tem em volta.

9 "Ta cheia?" pergunta a monitora sorrindo para a criança, enquanto se vira para conversar com outra responsável que está no refeitório.

10 Após mastigar, Rosa pega a colher que a M2 já havia separado e coloca na boca, nesse momento, a monitora apenas olha enquanto a criança come.

11 "Rosa após terminar, recebe um elogio da monitora "muito bem, comeu tudo, agora coloca o prato lá", Rosa se levanta, coloca o prato no balcão e se dirige para a sala."

No turno 1, Rosa após receber o prato entregue por uma das crianças que auxilia a monitora, senta e observa seus colegas, atenta a movimentação. A partir do turno 2, Rosa começa a comer sozinha, mas sempre olhando os colegas. Já no turno 3, é possível notar que os colegas que estão na sua mesa, também se alimentam sozinhos.Como descrito, apesar de haver outras crianças na mesa de Rosa, elas não conversam, comem em silêncio apenas observando a movimentação do refeitório. Rosa usa a mão para pegar um pedaço de carne e levar a boca, mas logo volta a utilizar a colher e usa a mesma para separar outro pedaço de carne, dessa vez batendo no prato para partir, assim como descrito no turno 4. No turno 5, Rosa começa a utilizar o utensílio para brincar sozinha, pois, enquanto mastiga, usa o talher para se divertir batendo na mesa.

Durante o tempo de observação a monitora se aproxima apenas em dois momentos, como é visto nos turnos 6 e 7, um para acariciar a cabeça da criança e outra para dar comida em sua boca. Visto que as crianças que demoram a comer já 
estão voltando para a sala, a monitora se aproxima de Rosa com o intuito de agilizar o término do jantar. Para isso a monitora pega o prato, separa a comida na colher e enquanto a criança mastiga, a responsável toca em seu braço com o utensílio e pede que Rosa coma, mas ao notar que a menina ainda está mastigando e distraída olhando para trás, a monitora muda sua postura e pergunta se a criança está cheia e logo se vira para conversar com uma outra responsável que passa na frente da mesa, como pode ser visto nos turnos 8 e 9 . Enquanto a monitora está terminando a conversa, Rosa pega colher que estava separada e coloca na boca para comer, no momento que a responsável volta sua atenção para a criança, apenas observa em silêncio a menina terminar de comer. Como aquela era a última colherada que faltava, a monitora elogia a criança e pede que a mesma coloque o prato no balcão, logo, a criança se levanta faz o que foi pedido pela responsável e se dirige a sala. Rosa demonstra ter bastante consciência corporal e espacial, segura os talheres com firmeza, utiliza as mãos para conter a comida que cai de sua boca, parte os alimentos quando necessário e brinca com os talheres, utilizando a forma canônica e convencional do objeto com propriedade.

Após o jantar, as crianças se dirigem a sala, escovam os dentes e seguem para a sala de vídeo, onde ficam até esperar seus responsáveis chegarem

Análise da janta

Durante as descrições pode-se observar que a preocupação com o tempo para acabar a refeição e ceder lugar as outras turmas se sobrepõe à autonomia das crianças. Dessa forma a monitora deixa passar uma ótima oportunidade de construção do conhecimento tanto de Rosa quanto de Íris.

Nas cenas descritas, podemos perceber que a comida das crianças possui texturas diferentes, o que facilita a identificação dos alimentos. Por sua vez, a monitora não fala sobre o assunto, assim como descrito na entrevista, não é explicado para as crianças qual será o cardápio do dia, o carboidrato utilizado ou a verdura que tem no prato, sua importância ou sua função no desenvolvimento e no seu organismo. Essa ação acaba inibindo a imaginação, estimulação e conhecimento sobre novos alimentos, tornando-se apenas uma função biológica e 
deixando de lado os aspectos culturais, pedagógicos, os valores de se alimentar e partilhar e a socialização que o processo permite apenas para os momentos de sala de aula, esquecendo os aspectos práticos, hábitos e rituais que envolvem esse alimento e o objeto.

Em sua resposta, a monitora fala em estimular, orientar e ajudar quando a criança não utiliza os talheres, algo que não está presente em sua prática, pois o modo como o alimento é servido às crianças dispensa qualquer explicação. A monitora parece não conhecer ou reconhecer os aspectos mais profundos e complexos envolvidos. Da mesma maneira, não são evidenciados os aspectos sociais, culturais e afetivos no Currículo em Movimento. Outro fato que chama a atenção na fala da monitora é quanto ao 'se alimentar com a ajudar da gente', é notório que essa fala se refere a alimentação na boca, pois não existe orientação, elas não são canalizadas a usarem os objetos para comer, dessa forma não é possível ocorrer um trabalho total da coordenação motora. Em um trecho da entrevista direcionado à monitora 1 é perguntado sobre a ação tomada quando a criança não usa o objeto, e o que fazem. A monitora prontamente responde e cita um exemplo: "Então, na nossa sala é a Íris, Íris aprendeu que se ela não comer, e esperar, ela pede ajuda, e vão lá e ajudam ela, eu não sou muito a favor de dar comida não, eu dou às vezes quando o tempo ta muito apertado e que tem outras turmas pra comer."

Ao ser questionada sobre a importância do diálogo durante a refeição, a monitora destaca o quão importante é para a educação das crianças, pois ali podem explicar que precisam comer tudo para ficar forte e evitar o desperdício. Apesar da resposta da monitora, é possível observar que existe uma discrepância entre o que é dito pela responsável e o que acontece na prática. É essencial notar a falta de diálogo entre as crianças e monitoras, foram poucos os momentos em que houve comunicação direta entre eles, que em grande maioria, foi direcionado a um problema explicito, como forma de correção ou a uma criança em específico, em grande parte as crianças que não comem sozinhas ou que se mexem e conversam mais durante a refeição. Diante disso é importante notar que a comunicação e alimentação espontânea por iniciativa das meninas ocorreram poucas vezes, 
comparada a quantidade de vezes que a monitora alimentou/direcionou sua atenção a uma situação específica com cada criança. Como pode ser visto no gráfico abaixo:

\section{FIgURA 2 - ComUNiCAÇÃo E ALIMENTAÇÃo}

- Caso Íris - Observação 2o dia

- Caso Rosa - Observação $9^{\circ}$ dia.

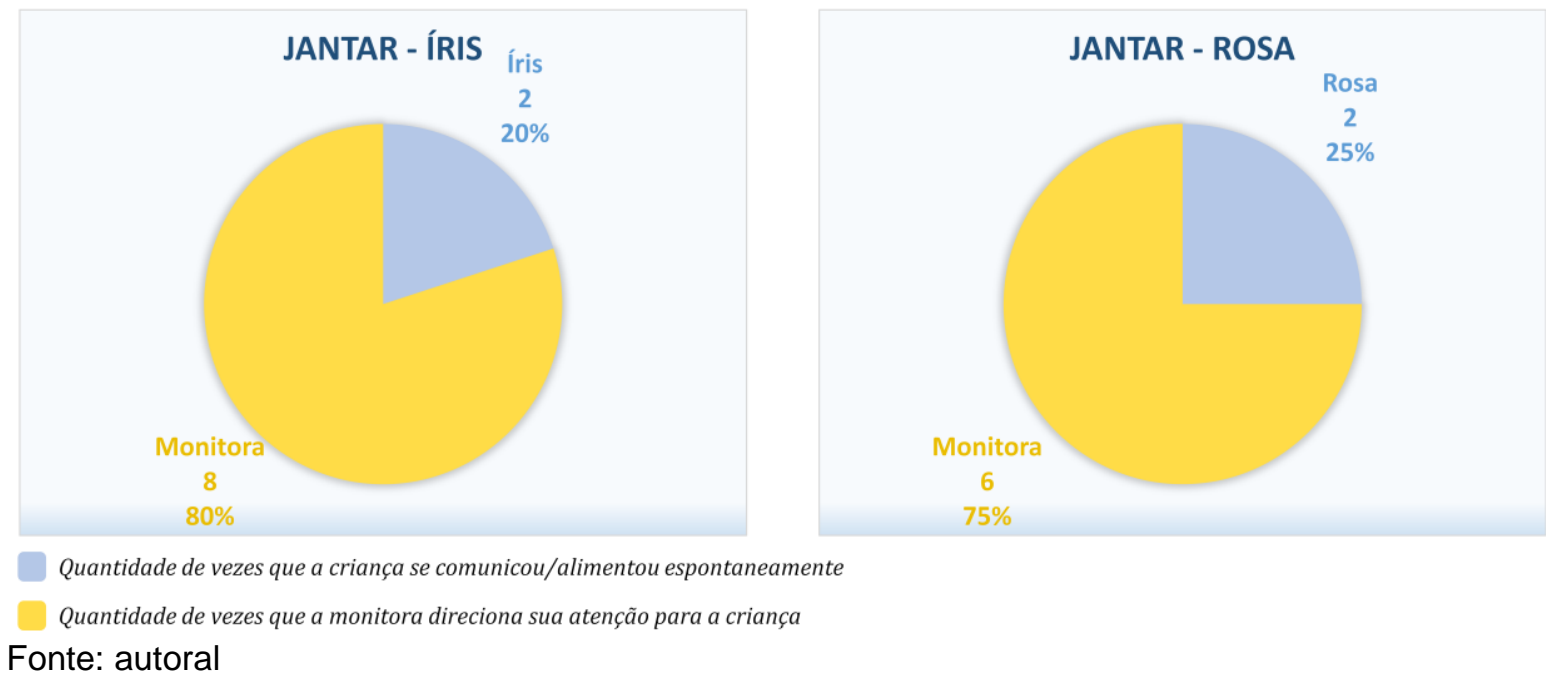

Em outra parte da entrevista é perguntado se esse diálogo é direcionado para crianças específicas, a monitora logo responde que sim e explica: "nas que tem mais dificuldades para comer, os que comem a gente utiliza assim: você ta vendo, o Cacto, ta comendo tudo ele vai ficar forte". Diante da fala da monitora, notamos que, apesar de reconhecer a importância do diálogo e do incentivo na forma como a criança se alimenta, a monitora concentra sua atenção no aluno que não come, de forma apenas biológica, sendo seu alvo principal a alimentação direta, usando de comparação para 'motivar' a criança à se alimentar. Não existe conexão entre as crianças e as monitoras, pela pressa em terminar antes da próxima turma, como a responsável mesmo fala, o diálogo se torna inexistente. A monitora não se envolve com as crianças, seu movimento parece automático, sempre repetindo o processo, enche a colher e leva a colher à boca da criança, de forma mecânica. Em consequência a pouquíssimas demonstrações de afetividade durante a refeição. 


\subsection{Análises de resultados}

A seguir serão analisados alguns momentos relevantes das observações. A análise estará focada nos turnos mais relevantes e serão discutidos a luz dos conceitos apresentados na fundamentação teórica. Iniciaremos com os relatos do almoço de Íris e Rosa e logo em seguida o jantar das respectivas crianças. Destacaremos algumas falas das monitoras a fim de elucidar os comportamentos tomados durante as observações.

\section{Observação almoço - Caso íris}

Como analisado na observação do $4^{\circ}$ dia, nos turnos 1,3 , 4 e 5 é possível notar que existe uma ação repetitiva por parte da monitora, a mesma antecipa o movimento de Íris, fornecendo e deslocando o objeto na bancada para a criança. Apesar de ESPAÑOL (2004) confirmar que "os gestos são signos nos quais se encontra uma clara intenção comunicativa", não houve um primeiro fornecimento de signo pela criança, pois, antes que Íris chegasse a bancada a monitora já estava lhe oferecendo o prato, tal ação inibe o primeiro contato direto com o objeto, tirando da criança a opção de escolher o utensílio empilhado. Íris durante todo o período do self-service no almoço, apesar de sempre demonstrar interesse em realizar as ações sozinha, foi auxiliada pela monitora mesmo não tendo solicitado ajuda a responsável. Não tendo a oportunidade de experimentar concretamente sua autonomia, estando limitada aos movimentos da monitora.

\section{Observação almoço - Caso Rosa}

Como analisado na observação do $4^{\circ}$ dia, nos turnos 4 e 5, Rosa chega na bancada e começa a se servir (não houve intervenção pela monitora), segura a concha de feijão e se serve com firmeza e sem dificuldade, a monitora inicialmente não interfere na ação da criança, apenas dá uns toques no utensílio, mas por fim pega a concha da mão da criança e sacode colocando de volta a cuba, com intuito de não sujar a bancada. Nos turnos seguintes é notória a diferença de ação da segunda monitora, a mesma espera pacientemente que Rosa coloque a comida as verduras em seu prato e só interfere para indicar que a quantidade colocada já é suficiente. No turno 10 a criança se vira para os colegas alegremente e pergunta: 
"Quem quer, quem quer, quem quer?". Porém como visto no turno 11 "A monitora olha com um ar de reprovação e sem entusiasmo diz: "A Rosa quer". A ação da monitora causou um constrangimento na criança, que logo ao receber a negativa, colocou a comida na boca e seguiu em silencio se alimentando. De acordo com ISHIGURO (2014), as crianças são capazes de aprender com um ambiente/espaço comunicativo, compartilhado e mutuamente disponível entre os participantes em que falam e compartilham conhecimento, podendo adquirir meios para viver uma vida saudável. Diante disso, a postura e a maneira que a monitora usa pra se comunicar com a criança pode influenciar no comportamento futuro da menina, pois elas tendem a reproduzir costumes e hábitos aprendidos. Uma vez que recebe a ação negativa da monitora, a possibilidade da ação espontânea da criança se repetir se torna cada vez menor. É interessante destacar que a bancada no qual estavam disponibilizadas as cubas eram do tamanho de mesas escolares, a altura não era apropriada para crianças pequenas (caso de Íris), pois dificultava a locomoção da colher dentro do objeto, deixando as crianças pequenas restritas apenas aos alimentos que estava na parte frontal interna da cuba. A possibilidade de apropriação dos usos desses objetos por parte das crianças se tornava restrito, pois além de alguns utensílios serem mais pesados, a disponibilidade do alimento não favorecia a pegada correta sobre o talher. As crianças ficavam dependentes das monitoras, pois necessitavam da ajuda das responsáveis para se servir. Esse pequeno empecilho poderia causar um incomodo nas crianças, pois toda vez que quisessem colocar mais comida, teriam que pedir a responsável para fazê-lo. Nesse caso, a ideia de alimentação e comunicação como espaço de promoção de autonomia se torna nulo, o momento no refeitório que é passível a exploração, comunicação e experimentação dos objetos, não introduzem uma vivência completa para as crianças pequenas. É importante relembrar que, nessa tríade o adulto possui um papel crucial no desenvolvimento dessas ações, visto que a primeira referência da criança são seus responsáveis, e toda ação realizada pelos mesmos, serão reflexos dos ensinamentos aprendidos.

Observação do Jantar - Caso Íris

Como analisado na observação do $2^{\circ}$ dia, nos fragmentos da cena 3 , é possível observar que durante toda a refeição a atenção da monitora está voltada 
para a criança. A responsável alimenta a criança na boca dado que a mesma não come sozinha, pois sabe que se esperar alguém chegará para dar-lhe comida, segundo informações passadas pelas próprias monitoras. No turno 7 a monitora um pouco apressada diz a menina: "Bora Irisinha, quer que eu conte pro papai que você não está comendo?", a monitora adverte a criança de uma forma bruta, sem pensar nas possibilidades que aquelas palavras poderiam ter sobre Íris. No turno 8, "Com um olhar de susto, Íris levanta o rosto e responde Não", e novamente no turno 9 a monitora rispidamente responde: "Então come" retruca a monitora, já levando a comida em direção a Íris que abre a boca.".De acordo com a fundamentação teórica já apresentada, pode-se destacar o trecho a seguir: "o sorriso expresso pela criança, é um reflexo da expressão de felicidade que foi fornecida da mãe, assim como quando a responsável muda sua expressão, a resposta visual da criança se modifica."

O mesmo ocorre com Íris, suas ações e expressões estão estritamente ligadas a monitora que a alimenta, no momento em que recebe uma expressão e fala negativa, sua resposta visual e corporal se alteram, a fim de se enquadrar no que foi passado pela responsável.

\section{Observação do Jantar - Caso Rosa}

Como analisado na observação do 9ำ dia, nos fragmentos da cena 2, Rosa recebe o prato e come sozinha durante quase o tempo todo do jantar, a criança não se comunica com os colegas de mesa e tampouco conversa com as monitoras que estão dando atenção as crianças das outras mesas. No turno 5 a criança brinca sozinha com a colher que está usando, batendo-o na mesa, como já visto na fundamentação teórica, 'para a criança realizar ações simbólicas, é preciso ter se apropriado do uso convencional anteriormente'. A monitora se aproxima e coloca a cadeira ao lado da criança e começa a alimentá-la, mesmo sem receber sinal de pedido de ajuda por parte da criança, a responsável realiza tal ação após a maioria dos alunos terem voltado para a sala, com o intuito de agilizar a alimentação de Rosa. De acordo com RODRíGUEZ (2009, p. 172), a intencionalidade comunicativa representa um avanço muito importante no desenvolvimento infantil, no qual se dá início a um triângulo comunicativo entre a criança, o objeto e o adulto, o que chamamos de triadicidade. 
No caso de Rosa, a comunicação intencional ocorreu primeiramente por parte da monitora, ao se aproximar para alimentá-la. 


\section{CONSIDERAÇÕES FINAIS}

Neste trabalho de final de curso, tivemos como objetivo geral analisar os diálogos e as ações expressas em contextos presentes nos usos dos objetos em situações alimentares na escola, desde uma perspectiva triádica. E como objetivos específicos caracterizar os diálogos expressos ao longo de diferentes momentos de alimentação e analisar os usos dos objetos que ocorrem no âmbito escolar ao longo dos momentos que envolvem a partilha dos alimentos. A observação e análise foram focadas nas ações que emergiram nas crianças e na intercepção pedagógica por parte dos educadores. Caracterizamos as ações que promoveram o uso convencional e autônomo dos objetos, bem como a organização da alimentação considerada como momento de aprendizagem. Descrevemos os objetos presentes e os usos por parte das crianças durante a alimentação. Identificamos as formas de interação com os adultos e a apropriação dos usos convencionais dos objetos durante a alimentação. Identificamos as formas de interação crianças-objetosadultos que permitiram ou restringiram a apropriação dos usos convencionais dos objetos durante as refeições. As análises foram feitas com base nas observações na creche e de acordo com o respaldo teórico pesquisado, a fim de compreender as ações e mediações pedagógicas que ocorreram durante as refeições.

Para isso, foi escolhida uma creche pública conveniada do governo, com funcionamento integral. Inicialmente o objetivo era analisar as ações e diálogos que surgiam durante os momentos de alimentação a respeito do uso convencional dos objetos.

No entanto, apesar de descrito no PPP da instituição que as monitoras participam de formação continuada uma vez por semana, no qual é trabalhado o Currículo em Movimento, não foi notado durante os dias de observação nenhum comentário sobre tal tema. Ainda segundo a documentação da creche, a instituição recebe um papel facilitador na formação do hábito alimentar, além de promover a educação nutricional. Ação que está de acordo com as metas estabelecidas no Plano Distrital de Educação (Lei no 5.499, de 14/7/2015).Ainda de acordo com a lei, a escola possui o Projeto Self-Service (projeto próprio), que tem por intuito favorecer e desenvolver a autonomia e o interesse das crianças e suas necessidades de escolha. De conformidade com a lei abaixo: 
- as crianças maiores devem ser incentivadas a servirem o seu próprio prato, com o apoio do adulto, e a mastigar bem os alimentos;

- as crianças devem ser estimuladas a apreciar os sabores, as cores, as texturas e a consistência de diferentes alimentos; (SEDF, 2013, p. 60)

Apesar da iniciativa favorecer a autonomia, o tempo e a limpeza das crianças parecem estar se sobrepondo ao trabalho pedagógico. A intenção não foi estabelecer obstáculos, porém, no decorrer do estudo, o confronto dos fatos encontrados nas observações com as entrevistasse tornaram necessários.

A pesquisa constatou que o momento de refeição é considerado uma pausa dos momentos de aprendizagem, se tornando em grande maioria uma necessidade apenas biológica. $\mathrm{O}$ momento no refeitório, mesmo sendo muito lúdico, prático e passível de exploração sobre os alimentos e objetos, não possuem abertura para diálogo sobre o tema, menos ainda de interação entre a criança-objeto-adulto.

As monitoras, no sentido teórico estão em conformidade com o contexto apresentado no referencial teórico apresentado e ás propostas de RODRIGUEZ (2009), referente ao uso dos objetos. Os objetos têm uma carga e um viés cultural e têm funções e regras de uso públicas. Além disso, os objetos sugerem um uso correspondente, que deveria ser regularmente explicado e conversado com as crianças, para que essas possam fazer a apropriação de seu uso convencional. Além disso, os objetos podem ser valorizados como elementos que carregam aspectos sobre a alimentação, os modos de preparo e as tradições e crenças existentes ao redor eles.

Os trabalhos pedagógicos em torno do uso convencional dos objetos pouco aparecem no contexto da creche, não é conversado regularmente, ensinado ou falado sobre eles. É fundamental nesse momento, a importância do papel das responsáveis no planejamento da rotina e organização com as crianças. Para isso, é necessário haver mudanças no contexto das creches e na postura das monitoras, outro fator a ser destacado, é a carência de profissional formado na área, e com os devidos aperfeiçoamentos, a fim de unir a teoria com a prática, melhorando a atuação na escola. 


\section{REFERÊNCIAS}

BRANCO, Angela Uchoa. Estratégias metacomunicativas nas interações criança - criança. Temas psicol., Ribeirão Preto, V.4, N. 3, P. 07-18, Dez. 1996.

ESPAÑOL, Silvia. Cómo hacer cosas sin palabras: Gesto y ficción en la infancia temprana.

KRAMER, Sonia. Infância e produção cultural. Campinas: Papirus, 1999

. Lei de Diretrizes e Bases da Educação Nacional: Lei no 9.394/96 - 24 de dez. 1996. Estabelece as diretrizes e bases da educação nacional. Brasília, 1996. Disponível em: < https://www.planalto.gov.br/ccivil_03/Leis/L9394.htm

PIAGET, J. O nascimento da inteligência na criança. 2. ed. Rio de Janeiro: Zahar, 1975 (1936).

INEP, 2015.

Plano Distrital de Educação - PDE/Ministério da Educação. Brasília, DF:

PROJETO POLÍTICO PEDAGÓGICO da escola pesquisada

RAPPAPORT, Clara Regina. Teorias do Desenvolvimento. Editora Pedagógica e Universitária. Volume 1, volume 2. 2005.

RODRÍGUEZ, Cintia. O nascimento da inteligência: do ritmo ao símbolo. Porto Alegre: Artmed, 2009.

SEDF. Currículo em Movimento da Educação Infantil. Brasília: GDF, 2013.

WESTRCH, J. V. A necessidade a ação na pesquisa sociocultural. In: WERSTCH, J. V.; DEL RíO, P.; ALVAREZ, A. Estudos sociais da mente. Porto Alegre: Artmed, 1998a. p. 56-71. 


\section{APÊNDICES}

\section{APÊNDICE A}

Roteiro da Entrevista semiestruturada - Nutricionista

1. Como surgiu a ideia do Projeto self-service?

O projeto é um dos projetos da associação Flor de Lis*, e a nutricionista da época tiveram a iniciativa por conta de incentivar a autonomia, coordenação motora e as escolhas alimentares. Não é um projeto da Jasmin*, é um projeto de todas as instituições geridos pela Flor de Lis*.

*Nome alterado para preservar a identidade da instituição.

2. Qual o objetivo principal do projeto?

Objetivo: Incentivar a autonomia, coordenação motora e incentivar boas escolhas alimentares.

3. Qual o tipo de melhoria notou com a implementação do projeto?

Tem toda a parte da Nutrição e do Pedagógico envolvidos. Na parte pedagógica é eles terem toda esse movimento, noção de peso, equilíbrio, saber a hora de saber se alimentar no sentido de, colocar meu prato, esperar o coleguinha servir o arroz, eu tenho que servir meu arroz, além de favorecer as escolhas alimentares, olhando aquele alimento, possam escolher.

4. Se a criança não quiser comer um dos alimentos oferecidos? Colocamos mesmo assim, porque nessa idade eles não tem completa autonomia, eles mal sabem todos os alimentos que estão consumindo, não dá pra gente dar um completa autonomia nessa faixa etária porque não convém, né, então assim, e muitas vezes eles vão com pré-conceito, né, o que a gente chama de, neofobialimentar, é o medo de experimentar o nome, é uma característica dessa faixa etária, então se deixarmos eles escolherem o que querem comer, logico que criança vai escolher o que é mais fácil, então a gente acaba colocando como uma forma que ele conheça, e ele conhecendo já coloca por 
si só. Tem crianças que são mais resistentes, e tem que outras que já comem melhor.

5. O projeto foi implantado quando? Implantado ano passado, desde o início da instituição.

6. Foi apresentado aos professores alguma instrução sobre passar a alimentação? É feito um treinamento, né, tanto no início do ano quanto no meio do ano, e ao longo desse período também, havendo alguma discordância, a gente, né, observando que elas estão procedendo de alguma forma que não seja correta, a gente intervêm também nas coordenações.

7. E as crianças que não comem sozinhas, como é feito o procedimento? $A$ gente começa a dar na boca e estimula para que ela coma sozinha, né, tem criança que tem essa dificuldade, justamente pela falta dessa independência em casa, então aqui a gente tem que ficar o tempo todo estimulando, e tem criança que tem dia que não ta afim de comer sozinha, né, que tem dia que ta com preguiça, então a gente tem que fazer essa oferta.

8. É passado algum treinamento aos pais? A gente explica, no início do ano a gente tem a reunião de início de ano, então a gente passa para os pais os projetos que a gente tem e os projetos que a gente cita é justamente o Selfservice pra que eles estimulem isso em casa também.

9. Quais melhorias você notou como nutricionista? Aumento de consumo, e agora a gente percebe nitidamente até a melhora na coordenação motora né, quando eles começaram, eles não conseguiam colocar por exemplo o feijão, que a colher é mais pesada, o pegador de salada, eles tinham dificuldade então isso já melhorou demais, mas principalmente realmente a ingestão de alimentação, quando chegaram aqui eles tinham muita dificuldade para comer os legumes, então com o self-service eles ficam curiosos, e a gente trabalha que tudo que coloca no prato eles vão ter que pelo menos experimentar, senão as vezes eles querem colocar pela euforia de usar o utensílio. 
10. A quantidade de alimento vocês controlam? É tudo controlado, existe um posicionamento recomendado por faixa etária, ela tem esse posicionamento, e elas ficam auxiliando as crianças porque eles até então não sabem a quantidade, então elas falam: três colheres, mais uma, não, ta bom, chega, então elas que dão esse norte para as crianças.

11. Self-service é implantado a partir de que idade? A partir dos dois anos.

12. Quem acompanha as crianças no almoço? A professora e as duas auxiliares.

13. É explicado para as crianças o cardápio do dia? O almoço a gente tem o habito e é orientação passado para as professoras, trabalhar os legumes principalmente por dia, então elas vão la na cozinha buscam os legumes que vão ser oferecidos naquele dia e elas trabalham na rodinha, explicando, então, hoje tem abobrinha, olha a abobrinha, cheira a abobrinha, pega a abobrinha, para eles terem contato. Agora o jantar não, o jantar eles ficam sabendo na hora que vai ser servido. Todo dia é trabalho na rodinha.

14. Os utensílios da cozinha foram apresentados? Qual a frequência que ocorre essa apresentação? A gente apresentou no início do projeto, então sempre que eles vão iniciar o self-service no início do ano a gente faz esse conhecimento dos objetos, mas ao longo do projeto eles devem orientar, mas não que seja uma obrigatoriedade.

15. Quanto a Cuba, onde ficam os alimentos, foi apresentado? Não sei te dizer se eles apresentaram a cuba, eu sei que as colheres, essas coisas, eles apresentaram sim.

16. Notou retrocesso em alguma criança? Sempre tem, sempre tem, mas é uma coisa bem característica da faixa etária deles, que eles começam a ter um pouco mais de autonomia, e essa autonomia às vezes retrocede. Às vezes por, tenho crianças que comia super bem, sozinha, mas o irmãozinho nasceu 
ai parou de comer, porque né vem a chegada do irmão, a mãe da mais atenção pro irmão do que pra ele, então eles usam de suas artimanhas pra chamar atenção. Eles acham que dar comida na boca é uma forma de carinho.

\section{APÊNDICE B}

Roteiro da Entrevista semiestruturada - Monitora 1

1. É apresentado para as crianças o que irão comer naquele dia? Só na hora, na hora que a gente coloca a comida lá, elas veem o que vão comer, mas antes da gente ir, a gente não apresenta não.Nemno almoço, jantar? Não, não.

2. Você acha que a alimentação tem uma função na aprendizagem e desenvolvimento das crianças? Tem, acho que tem grande influência nessa questão pedagógica, porque é a forma como as crianças mesmo sabendo o que comem, a gente fala ó, você está comendo isso pra ficar mais forte, abobrinha, essa é a abobrinha ela é verde, a gente utiliza de meios pedagógicos e não somente para alimentação deles.

E os objetos? Sim, sim, eles se servindo trabalham vários movimentos, tanto grossos como finos, pegar a colher, levar até a boca sem derramar, trabalha o equilíbrio da criança, ela consegue pegar o prato dela e levar até a cozinha que é um lugar mais alto, ela tem que equilibrar o prato até lá para colocar lá em cima.

3. Você explica o uso dos objetos que dispõem as crianças no refeitório? Como explica? Eu não me lembro da gente ter explicado, eu acho que quando, no começo do ano quando eles começaram a se servir a gente explicou, esse aqui é pra pegar o feijão, você leva o feijão, o pegador você pega desse jeito, e usa pra pegar a salada, eu acho que pegador assim, a gente explicou por conta que eles ainda estavam aprendendo a se servir, ai depois dessa vez que a gente explicou cada um a gente não falou mais, foi só no início do ano quando eles estavam aprendendo a se servir. 
4. As crianças usam os talheres e pratos sem dificuldade? Quando não usam, o que fazem? Não, acho que eles usam bem. A concha é um pouco mais complicada nos que são mais baixinhos, mas eles conseguem com certa dificuldade, mas conseguem por conta da altura, mas os outros eu acho que eles comem bem assim.

É desde o início do ano ou é um trabalho progressivo? Eles sabiam utilizar, mas não pegavam de um jeito correto, a gente trabalhou pra eles usarem assim, para que não caísse da colher, não sujasse a mesa, mas foi uma coisa trabalhada.

Quando não usam, o que fazem? Então, na nossa sala é a Íris, Íris aprendeu que se ela não comer, esperar, ela pede ajuda, e vai lá e ajuda ela, eu não sou muito a favor de dar comida não, eu dou as vezes quando o tempo ta muito apertado e que tem outras turmas pra comer.

5. Você acha que a criança faz uso desses objetos em casa?

Então, as crianças todas sim eu acho que eles utilizam a colher, eles não se servem em casa, mas colher e garfo, colher e prato eles usam.

6. O que a criança pode desenvolver e aprender usando os objetos presentes nesse local? Acho que ela toma ciência do próprio corpo porque ela tem que segurar com as duas mãos, porque com uma eles não conseguem, o prato cai, tem que segurar com as duas mãos, levar, aí como tem a mesa, tem que ir lá colocar o prato, soltar, depois ir subir sem o prato, porque senão já cai. No começo do ano dava pra ver que eles tomaram consciência disso, porque antes eles tentavam subir com o prato e tentavam levar o prato só com uma mão, ai tudo ia caindo, no começo tudo caía, e ai eles tomaram consciência que era melhor levar com as duas mãos, eles aprenderam a ter mais equilíbrio, porque quando eles vão subir na, deixar o prato e colocar, como tem um espaço eles tem que ficar na ponta do pé, então exige um equilíbrio muito maior pra eles colocarem a colher, quando eles vão jogar o resto que sobra alguma de comida e eles jogam no lixo, eles aprenderam que, agora não, mas antes tinha que colocar o pé na lixeira pra ela levantar e depois eles tinham que pegar o prato com uma mão, a colher com a outra pra fazer esse movimento, isso tudo ao mesmo tempo, 
se não, não dava certo, e demorou, até eles tomarem consciência do equilíbrio da força que eles tinham que usar no pé demorou, e colocar tudo no pé, demorou

7. Em relação ao self-service, foi notado melhora em relação aos ambientes desde o início do ano? Eles melhoraram bastante, esse ano eles conseguiram, pois não conseguiam. Fomos orientando, orientando e hoje eles já conseguem.

8. Vocês acham que é importante esse dialogo durante as refeições? Sim, acho que é muito importante, porque é uma forma que a gente tem de estar educando eles ali, e explicar pra eles que tem que comer pra ficar forte, vamos comer tudo pra não jogar fora. $E$ depende muito da criança, cada criança tem que falar de um jeito diferente, porque tem criança que você fala, não, você tem que comer porque a mamãe vai ficar feliz, ou tem que criança que a gente usa até, a você tem que comer porque vai ficar forte que nem o Super-Homem, que nem o Hulk ou que nem, depende de cada criança e é extremamente importante isso porque se, tipo, eles gostam de comer sim, mas se tiver algo mais atrativo que a comida, eles vão preferir ir, eles não querem, eles não vão querer, é preciso que a gente através da conversa que é o que a gente ta ali, incentivem eles a comer. A gente usa diversos meios através da comunicação para incentivar. Mas faz com crianças específicas? Sim, as que têm mais dificuldades para comer, os que comem a gente utiliza assim, você ta vendo o VENUS ta comendo tudo ele vai ficar forte, como título que comparação com os outros.

\section{APÊNDICE C}

Roteiro da Entrevista semiestruturada - Monitora 2

1. É apresentado para as crianças o que irão comer naquele dia? É feita apenas no almoço? É feito no almoço, levamos os legumes, aí a gente fala, vamos comer arroz, feijão, carne, cenourinha, beterraba, a gente leva alguns dos legumes.

2. No momento do jantar é apresentado, ou é descoberto na hora o que vão comer? Não, no jantar não, descobrem na hora o que vão comer. 
3. Você acha que a alimentação tem uma função na aprendizagem e desenvolvimento das crianças? E os objetos tem função pedagógica ou apenas biológica? Com a função de aprendizado. A gente ensina como eles pegam a colher, como levar até a boca, como eles devem comer sem derramarem, sem jogar no chão, sem jogar nos colegas. Tem função pedagógica.

4. Você explica o uso dos objetos que dispõem as crianças no refeitório? Como explica? Sim, não no refeitório, mas a gente em sala antes de vir para $o$ refeitório, a gente fala sobre a alimentação, como deve ser feita.

5. As crianças usam os talheres e pratos sem dificuldade? Quando não usam, o que fazem? Sim, nem todos sabem comer. A gente estimula eles, orienta e ajuda a gente sempre está ajudando, quando eles não conseguem comer com as próprias mãos, a gente faz com que eles se alimentem com a ajuda da gente.

6. Você acha que a criança faz uso desses objetos em casa? Sim.

7. O que a criança pode desenvolver e aprender usando os objetos presentes nesse local? A mastigar, a pegar a colher, a manusear os objetos.

8. Em relação ao self-service, foi notado melhora em relação aos ambientes desde o início do ano? Eles melhoraram bastante, esse ano eles conseguiram, pois não conseguiam. Fomos orientando, orientando e hoje eles já conseguem. 


\section{ANEXOS}

\section{TERMO DE CONSENTIMENTO LIVRE E ESCLARECIDO}

Você está sendo convidado (a) para participar, como voluntário, em uma pesquisa. Após ser esclarecido (a) sobre as informações a seguir, no caso de aceitar fazer parte do estudo, assine ao final deste documento, que está em duas vias. Uma delas é sua e a outra é do professor responsável. Em caso de recusa você não será penalizado (a) de forma alguma. Em caso de dúvida você pode procurar o professor/orientador Francisco José Rengifo-Herrera (frengifo@unb.br) na Universidade de Brasília.

\section{INFORMAÇÕES SOBRE A PESQUISA:}

Título do Projeto: Os processos de alimentação na Educação Infantil: Estudo de caso sobre a prática no ambiente escolar com crianças de três anos.

Pesquisadora: Gisele Karolina Nascimento de Freitas. Matricula: 14/0141740

Pesquisador responsável: Francisco José Rengifo-Herrera

E-mail para contato: frengifo@unb.br, gih_karolina@hotmail.com

- Este trabalho visa analisar as ações e diálogos expressos ao longo de diferentes momentos de observação, em situações de alimentação de duas crianças de três anos no contexto escolar. A observação e análise serão focadas nas ações que emergirem nas crianças e na intervenção pedagógica por parte dos educadores. Objetivo é analisar as ações, diálogos e posicionamentos que surgem durante os momentos de alimentação a respeito do uso convencional dos objetos no contexto educacional. Buscaremos caracterizar as ações que promovam o uso convencional e autônomo dos objetos, bem como a organização da alimentação considerada como momento de aprendizagem. Descreveremos os objetos presentes e os usos por parte das crianças durante a alimentação. Identificaremos as formas de interação com os adultos e a apropriação dos usos convencionais dos objetos durante a alimentação.

- Esclareço que a identificação da Instituição, dos professores e crianças serão mantidos em absoluto sigilo e que as informações obtidas serão utilizadas unicamente para a discussão nesta pesquisa;

- Não pretendemos realizar apenas um diagnóstico, como também abrir um espaço de reflexão com a instituição. 
- O estudo será realizado com 11 observações na escola durante os turnos matutino e vespertino, cujo foco será dado as refeições das crianças, juntamente com a entrevista semiestruturada realizada com as monitoras;

- O projeto pretende analisar os usos e significações que os objetos têm na prática cotidiana no refeitório. Registro de áudio, fotos (conservando o sigilo e a identidade dos envolvidos e entrevistas com os participantes farão parte do processo de construção de dados) para análise microgenética dos diálogos e posicionamentos que emergirem durante a pesquisa;

- É garantida expressão de liberdade de retirar o consentimento, sem qualquer prejuízo da continuidade do acompanhamento/ tratamento usual.

\section{- CONSENTIMENTO DA PARTICIPAÇÃO DA PESSOA COMO SUJEITO} $\mathrm{Eu}$, RG/ CPF/ n.ำ de prontuário/ n.ำ de matrícula abaixo assinado,

concordo em participar do estudo
$\begin{array}{rlll}\text { devidamente informado e esclarecido } & \begin{array}{r}\text { como } \\ \text { pelo }\end{array} \text { pujeito. Fui } \\ \text { pesquisador }\end{array}$ sobre a pesquisa, os procedimentos nela envolvidos, assim como os possíveis riscos e benefícios decorrentes de minha participação. Foi-me garantido que posso retirar meu consentimento a qualquer momento, sem que isto leve a qualquer penalidade ou interrupção de meu acompanhamento/ assistência/tratamento. Local e data Nome e Assinatura do sujeito ou responsável: Presenciamos a solicitação de consentimento, esclarecimentos sobre a pesquisa e aceite do sujeito em participar Testemunha (não ligada à equipe de pesquisadores): Nome: Assinatura: 